\title{
The Poison Pill Anti-takeover Defense: The Price of Strategic Deterrence
}

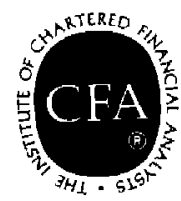

The Research Foundation of

The Institute of Chartered Financial Analysts 


\section{The Poison Pill Anti-takeover Defense: The Price of Strategic Deterrence}


(C) 1991 The Research Foundation of the Institute of Chartered Financial Analysts

All rights reserved. No part of this publication may be reproduced, stored in a retrieval system, or transmitted, in any form or by any means, electronic, mechanical, photocopying, recording, or otherwise, without the prior written permission of the copyright holder.

This publication is designed to provide accurate and authoritative information in regard to the subject matter covered. It is sold with the understanding that the publisher is not engaged in rendering legal, accounting, or other professional service. If legal advice other expert assistance is required, the services of a competent professional should be sought.

From a Declaration of Principles jointly adopted by a Committee of the American Bar Association and a Committee of Publishers.

ISBN 10-digit: 0-943205-11-5 ISBN 13-digit: 978-0-943205-11-3

Printed in the United States of America

Charlene Semer, Editor

Joni L. Tomal, Production Editor

Diane B. Hamshar, Typography/Layout

May 1991 


\section{Mission}

The mission of the Research Foundation is to identify, fund, and publish research material that:

- expands the body of relevant and useful knowledge available to practitioners;

- assists practitioners in understanding and applying this knowledge; and

- enhances the investment management community's effectiveness in serving clients.

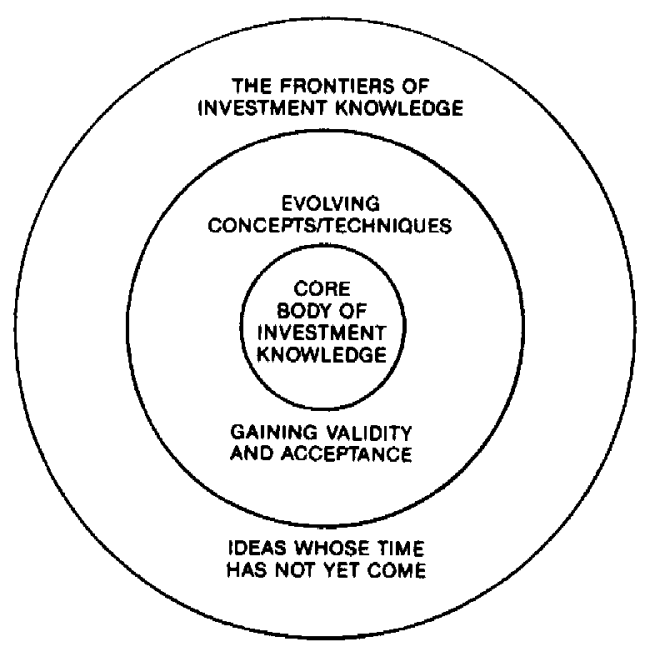

The Research Foundation of

The Institute of Chartered Financial Analysts

P.O. Box 3668

Charlottesville, Virginia 22903

(804) $977-6600$ 


\section{TABLE OF CONTENTS}

Acknowledgments ................. . . . . .

Foreword $\ldots \ldots \ldots \ldots \ldots \ldots \ldots \ldots \ldots$

Chapter $1 . \quad$ Introduction $\ldots \ldots \ldots \ldots$

Chapter 2. Mechanics of the Poison Pill ... . . . . . 5

Chapter 3. Impact of the Pill on Shareholder Welfare . . . 17

Chapter 4. Simulating the Effect of a Poison Pill . . . . . . . 29

Chapter 5 . Survey of the Current Controversy . . . . . . . . 39

Chapter 6. Conclusions . . . . . . . . . . . . . . . 499

Appendix 1. Evolution of the Poison Pill . . . . . . . . . 51

Appendix 2. The Williams Act of 1968 . . . . . . . . . . 65

Appendix 3. Technical Supplement to the

Simulation Analysis . . . . . . . . . . 699

Glossary of Terms . . . . . . . . . . . . . . . . .

References $\ldots \ldots \ldots \ldots \ldots \ldots \ldots \ldots \ldots$ 


\section{ACKNOWLEDGEMENTS}

Thanks go to Charles A. D'Ambrosio, Michael P. Dooley, and Robert S. Harris for valuable comments and to Mark Burget, Robert Hogland, Mark Shroeder, and Larry Weatherford for research assistance. The research for Appendix 1 was compiled by Mark A. E. Burget. Appendix 2 and the Glossary of Terms were prepared by Mark Schroeder. The Darden Business School Sponsors, University of Virginia, provided financial assistance for the research. Although this discussion necessarily touches upon the legal ramifications of poison pills, nothing herein is intended to be a substitute for qualified professional legal counsel.

Robert F. Bruner

University of Virginia 


\section{FOREWORD}

Poison pills are invasive of the financial politic and sometimes evoke deeply felt emotions that impede the application of sound financial principles. Thanks to Bruner, we have an objective analysis of what, to some, is one of the greatest outrages foisted on the financial community and, to others, is a natural-law right of shareholder-elected management.

Bruner addresses most of the questions that spark such strong reactions to the use of the poison pill defense against corporate takeovers. For example,

- Do poison pills harm shareholders?

- If so, how much?

- Are poison pills effective anti-takeover deterrents?

- Do they extract higher payments from bidders?

- How are the potential gains from restructuring related to the effects of poison pills on shareholder wealth?

- Is legislation needed to prohibit poison pills or to regulate them more closely?

Bruner's analysis highlights the disparity between two tenets of financial theory. The first is that maximizing shareholder value is the only legitimate financial goal of an enterprise. The second is that all stakeholders have an interest in the welfare of an enterprise. Poison pills stand squarely in the center of the conflict between these two institutional precepts-management's discretion to manage as it sees fit, and the shareholders' expectation that the firm will be managed for their exclusive welfare. This is the context for Bruner's skillful analysis: shareholder wealth maximization, bounded by the interests of management. As you travel with him, remember that, although many firms have adopted a poison pill, this defense is usually so stringent and discouraging to potential acquirers that no pill has ever been triggered-at least deliberately. Even the most draconian "shark repellents" seem mild palliatives in comparison.

After a brief introduction, Bruner explains the construction and purposes of a typical poison pill. The exercise not only is instructive but also is necessary to an understanding of the nature of this intricate device. He continues by describing various types of pills. The anti-takeover process has spawned some of the more colorful language in the business of finance. The glossary Bruner provides is a life saver.

Bruner's analysis of the impact of the poison pill on shareholder wealth is elemental, true to the mark, and analytically correct. He cites many relevant empirical studies. Persuasive arguments exist on both sides of the gain/loss 
question, but empirical testing cannot measure the loss of opportunity that might result from driving away potential bidders. Bruner's solution is to simulate the potential gain from restructuring and compare it with the potential loss that the poison pill may occasion. With the elements juxtaposed thusly, and conducted within reasonable real-world parameters, the analysis is enlightening and valuable.

Companies that have a proclivity for adopting poison pills are characterized according to financial performance. The question is, Does underperformance cause firms, when threatened, to adopt poison pills? Or do they arise from principles of corporate governance? The evidence Bruner presents suggests that poor performance is likely to be a condition precedent to poison pill creation. Also, poison pills tend to be adopted by managements with small ownership positions.

No discussion of poison pills is complete without addressing public policy issues. A hot and heavy debate about poison pill tactics raged in Congress in 1987 , and it continues today in state legislatures. Recently, a small but vociferous group surfaced to express the concerns of institutional investors. Corporate governance, its general fairness, and the specific prerogatives of management are at the heart of the matter. The question? Do poison pills effectively undercut shareholder governance in corporations?

Bruner wraps up his presentation with three appendixes. The first retraces the fascinating legal evolution of poison pills. This bit of financial history enables us to interpret contemporary events better and to anticipate future ones. Appendix 2 describes the Williams Act of 1968, which amended the Securities Exchange Act of 1934 to regulate certain aspects of unsolicited acquisitions. Appendix 3 is the technical supplement to the simulation analysis, in itself an instructive exercise.

In commenting on the intricacies of poison pills, Bruner cites an attorney who observed that the most prized poison pill is one that obfuscates matters beyond the comprehension of most mortals. Because Bruner enlightens a sometimes murky, often confused, Byzantine concept, his research is to be prized by all investment professionals. The business implications are extensive. The Research Foundation is pleased to bring this work to its worldwide constituency.

Charles A. D'Ambrosio, CFA The Research Foundation of the Institute of Chartered Financial Analysts 


\section{Introduction}

"Nor should any state believe that it can always choose safe courses of action; on the contrary, it should think that they will all be doubtful; for we find this to be in the order of things: that we never try to avoid one disadvantage without running into another; but prudence consists in knowing how to recognize the nature of disadvantages and how to choose the least bad as good."

-Niccolo Machiavelli, The Prince

"Toto, I don't think we're in Kansas anymore."

-Dorothy in The Wizard of $\mathrm{Oz}$

The poison pill is arguably the most significant corporate financial innovation of the 1980s and certainly the most controversial. Like a tornado swirling innocents out of Kansas into the Land of $\mathrm{Oz}$, the pill swept business takeovers into a materially altered landscape and raised fresh controversy about the relationships among managers, directors, shareholders, and fiduciaries.

The pill's proponents are given to ringing endorsements such as: "Every company should have a state-of-the-art pill" (Lipton 1990). "There is no economic basis to oppose the implementation of rights plans" (John Wilcox, Managing Director of Georgeson \& Company, in Georgeson \& Company, Inc. 1988b). The pill's opponents are equally emphatic: "How is it useful for a management to make a commitment that could force actions that aren't in either the shareholders' or the company's interest?" (Peter Jacquith, quoted in Metz 1988). And,

Rights issues ... will fundamentally impair the efficiency of corporations that adopt them, and for this reason they will reduce productivity in the 
economy if widely adopted... The problem with these special securities ... [is] the manner in which they are being adopted-that is, without approval by shareholders. (Jensen 1986, pp. 26-27)

Previously the province of lawyers and investment bankers, the pill now warrants the attention of a broader audience-if for no other reason than that the pill defense is pervasive and its latent influence huge. By early 1990 , more than 1,000 publicly traded corporations had adopted the poison pill defense (Investor Responsibility Research Center survey reported in Mergers and Acquisitions 1990). These firms constituted 43 percent of companies listed on the New York Stock Exchange, the American Stock Exchange, and the National Association of Securities Dealers Automated Quotations System (Mergers and Acquisitions 1990, p. 20), or (conservatively) \$2 trillion of market value of equity. Virtually all major hostile tender offers of the late 1980 s involved litigation about the poison pill. ${ }^{1}$

The pill has yet to be swallowed (or triggered) deliberately by any company. It has been triggered accidentally, however. In September 1990, the management of the Instron Corporation inadvertantly triggered the company's poison pill when they announced that they and family members owned about 39 percent of Instron stock.

In addition to its pervasiveness, the pill is widely regarded as the most effective anti-takeover defense available. Even though more than two-thirds of firms with pills that have been targets of hostile tender offers eventually change ownership (Ryngaert 1988), the pill's proponents argue that it succeeds in motivating direct negotiation and in extracting higher prices from bidders. $^{2}$

The purpose of this monograph is to shed light on the pill's many subtleties, with particular attention to its economic effects and their implications

\footnotetext{
${ }^{1}$ The poison pill defense has spread beyond the borders of the United States-mainly to countries with Anglo-American traditions of corporate governance. Canada, for instance, saw a surge in poison pill adoptions in 1989, principally among large firms and among firms with shares listed for trading in the United States. For a fuller discussion of pill adoption issues in foreign countries, see, for instance, Coleman (1989), Macintosh (1989), and Neto (1990).

2،. . in hostile bidding contests, poison pills help maximize value for shareholders,"-John Wilcox, Georgeson \& Company. "[The pill] is the most effective way to equalize the negotiating strength of management with the overwhelming advantage that the corporate raider has."-Martin Lipton, quoted in Lee, (1988), p. C55.
} 
for the poison pill controversy. Important insights of this economic analysis include the following:

- The pill's power to harm a raider depends most importantly on its exercise price multiple-the ratio of the exercise price to the prevailing stock price. Unaccountably, the courts and legal and financial advisors give greater attention to other structural features of the pill such as purchase value and trigger percentage. The analysis here suggests that the exercise price multiple should command the greatest attention.

- In theory, a pill can either create or destroy value for shareholders. The outcome will depend on the balance of countervailing effects. Adopting a pill may signal that insiders believe the firm is worth more than its current trading price, but the pill deters outsiders from coming to offer their bids for the firm. The key consideration in estimating the pill's effect is the value of the firm under strategies the pill precludes.

- The numerical simulations reported here and the preponderance of research elsewhere suggest that the poison pill defense is costly to target-firm shareholders. How costly it is depends importantly on the uncertainty surrounding investors' forecasts of future stock prices and on future values of the firm if restructured. Greater uncertainty is associated with more negative effects of pill adoption.

- Simulation also reveals that the pill is an extremely effective deterrent. The pill has never been swallowed deliberately, because no rational raider would trigger the severely dilutive effects of the pill. When faced with a pill, a raider's only tactical response is to press directors, shareholders, and the courts to rescind it-a tactic that has succeeded in certain past situations but that is growing increasingly doubtful as a modus operandi.

Thus, the strategic deterrence afforded by the pill comes at a price. The informed and prudent manager and director, in deciding whether to adopt or rescind a pill, should carefully weigh the purported benefits of the poison pill defense against its costs. Similarly, shareholders, securities analysts, and fiduciaries should view with caution the plans of management to develop a pill defense. The growing activism by large institutional investors opposed to the pill is consistent with the view that the pill's strategic deterrence is too costly. 


\section{Mechanics of the Poison Pill}

The poison pill (or, more formally, "Shareholder Rights Plan") is an unusual call option to purchase on favorable terms securities in a target or bidding firm. This option is exercisable only under certain circumstances such as a hostile tender offer. The terms of most pills are extremely complex and varying. One lawyer commented, "An important deterrent value of a poison pill is that it is almost impossible for any raider to understand how it will work."

\section{The Structure and Objectives of a "Typical" Pill}

Under corporate law in most states, directors are empowered to issue stock purchase rights to their own shareholders, without the vote of those shareholders. Typically, the board issues one share-purchase right for each share of stock outstanding. This right is not detachable until triggered (that is, the right must trade with the associated share until it becomes exercisable). The right is exercisable only upon some triggering event such as when the bidder obtains (or even announces an interest in acquiring) target shares equal to some percentage of total shares outstanding. Early pills had triggers between 30 and 50 percent. Recently adopted pills have triggers at 10 percent. Corporations with early pills have sought, with mixed success, to lower their trigger percentages. ${ }^{2}$

When exercisable, the right typically allows the rightsholder to purchase shares of common stock at a considerable discount-an opportunity that is explicitly denied to the hostile bidder. The right will specify an exercise price,

\footnotetext{
${ }^{1}$ David R. King, quoted in Matthewson (1988a).

${ }^{2}$ In June 1990, a U.S. appeals court held that Avon Products could not lower the trigger for its poison pill. In July 1990, Delaware Chancery Court ruled that National Intergroup had to submit its amended plan to a shareholder vote before the plan could be declared effective.
} 
as well as the value of securities the exercise will obtain. For example, the shareholder might pay $\$ 100$ in cash for securities worth $\$ 200$, thereby obtaining a 50 percent discount on those securities. The discount is what imposes economic dilution on the bidder. The greater the difference between exercise price and market value, the more dilutive is the pill. The typical pill is structured with an initial purchase value multiple of two to four times current stock price.

The objectives of the pill are to impose unacceptable dilution on the acquirer; raise uncertainties about the acquirer's chance of success and cost to acquire; motivate the acquirer to negotiate with the board of directors; buy time for the board to determine the best course of action, and if necessary, auction the company in orderly fashion; and positively preemptcoercive bidder tactics such as partial and front-end-loaded tender offers (Block and Pitt 1990). How the pill achieves these objectives is best illustrated by a simple example.

\section{An Illustration: “Flip-In" Shareholder Rights Plan}

Suppose that your firm has adopted a pill with the following structural features:

For each old share of common stock in the firm, nonraider rightsholders may purchase common stock worth $\$ 200$ for an exercise price of $\$ 100$, if a raider acquires 20 percent of the shares outstanding.

The firm currently has 100,000 shares outstanding. Suppose that its current share price is $\$ 25.00$. No tender offer is currently outstanding. Management wishes to analyze the implications of the pill if triggered by a hostile takeover in which the bidder has offered $\$ 33.33$ per share. Management supposes that $\$ 33.33$ is the possible future stock price of the firm, available after the raider imposes his operating strategy on the firm.

Table 1 presents the results of this scenario supposing that all the rights are exercised. First, the right to purchase $\$ 200$ worth of stock entitles the owner of a share to buy $\$ 200 / 33.33$ shares (six new shares). In this instance, the 80,000 shares in public (nonraider's) hands could buy 480,000 shares $(6 \times$ 80,000 shares), bringing their total to 560,000 (line 1 ) and diluting the raider's percentage of votes from 20 percent to 3 percent (lines 4 and 5). Second, the pill effects a massive wealth transfer ( $\$ 276$ million) from the bidder (line 13) to the nonbidder shareholders (line 16) - equating to 8 percent of the pretrigger market value of equity. Third, even worse for the bidder, the remainder of the equity has become even more costly to acquire, by a multiple of nearly 


\section{TABLE 1}

\section{Mechanics and Wealth Effects of "Flip-In" Shareholder Rights Plan}

Assumptions

Current stock price:

Expected future stock price:

For each old share of common stock, nonraider shareholders have the right to: purchase common stock worth for a price of

Purchase multiple

Future exercise multiple

Current Exercise Multiple

Number of preexisting common shares outstanding:

Rights "trigger"

\section{Analysis of voting control \\ 1 Public shares post-trigger \\ 2 Shares held by raider \\ 3 Total resulting shares \\ 4 Raider shares/total \\ 5 Raider's voting dilution}

\section{Analysis of wealth and wealth transfer} (total values in thousands)

6 Pre-trigger equity value

7 Cash received upon exercise

8 Post-trigger equity value

9 Estimated ex post stock price

10 Value to public net of exercise price per old share

Total value of raider shares

11 Before trigger

12 After trigger

13 Raider's economic dilution
560,000

580,000

(\$276)

\section{Notes}

Raider's price to acquire

Purchase value

Exercise price

Purchase value $(\$ 200)$ /exercise price $(\$ 100)$.

Exercise price $(\$ 100) /$ raider's expected price to acquire ( $\$ 33.33)$.

Exercise price $(\$ 100) /$ current stock price $(\$ 25)$

$20 \%$

Stock price before triggering $(\$ 33.33) \times$ number of shares $(100,000)$.

Exercise price $(\$ 100) \times$ number of nonraider shares outstanding $(80,000)$. $^{\text {b }}$

Cash received from exercise + original market value.

Post-trigger equity value $(\$ 11,333) /$ total resulting shares $(580,000)$.

Estimated ex post stock price $(\$ 19.54) \times$ share multiple $(7)$ - exercise price per share.

Stock price $(\$ 33.33) \times$ raider's shares $(20,000)$.

Expected ex post stock price $(\$ 19.54) \times$ raider's shares $(20,000)$. 


\section{TABLE 1 (continued) Mechanics and Wealth Effects of "Flip-In" Shareholder Rights Plan}

Total value of public shares (net of exercise price)

14 Before trigger

\author{
$\$ 2,667 \quad$ Stock price $(\$ 33.33) \times$ number of shares \\ $(80,000)$. \\ $\$ 2,943$ \\ $\$ 276$
}

15 After trigger

16 Public's economic accretion

Analysis of cost to acquire all remaining shares

(\$ in thousands) ${ }^{c}$

17 Cost after trigger

18 Cost before trigger

19 Added cost to acquire

Estimate of total costs imposed on raider

(\$in thousands)

20 Added cost to acquire

$\$ 8,276 \quad$ (Line 19)

21 Economic dilution of shares currently owned

22 Total costs imposed

23 Costs/future market value of target ex ante

24 Costs/current market value of target ex ante
$\$ 10,943$

$\$ 2,667$

$\$ 8,276$

$\$ 276$

$\$ 8,552$

$257 \%$
Expected ex post price per share $(\$ 19.54) \times$ nonraider shares outstanding $(560,000)$. Stock price $(\$ 33.33) \times$ number of nonraider shares $(80,000)$.
Total costs imposed $(\$ 8,552) /$ market value of the firm at expected future price (\$33.33).

Total costs $(\$ 8,552) /$ market value of the firm at current stock price (\$25).

${ }^{a}$ For every share the nonraider shareholders owned ex ante, the triggering of the pill grants a multiple equal to:

$[($ Purchase value/Future stock price $)+1]=[(200 / 33.33)+1]=7$.

${ }^{\mathrm{b}}$ Assumes that all rights are exercised.

${ }^{c}$ Assumes no premium over stock price.

four times (lines 17-19). Finally, combining the economic dilution of shares currently held by the bidder (line 21) and the added cost to acquire the rest of the shares (line 20), the pill makes acquisition about two and one-half times more costly at the expected $\$ 33.33$ share price (line 23), or three and one-half times more costly than the current share price of $\$ 25.00$ (line 24 ). 
The key driver of the bidder's unhappy fate is the flood of new shares issued upon exercise of the rights, which will be a multiple of existing shares in the hands of nonbidder shareholders. For instance, the resulting shares in line 3 are determined by this formula:

\begin{tabular}{|c|c|}
\hline $\begin{array}{l}\text { Resulting } \\
\text { shares held by }=(1-\text { Trigger } \%) \times \\
\text { nonbidder } \\
\text { shareholders }\end{array}$ & $\begin{array}{l}\text { Outstanding } \quad \text { Pill } \\
\text { shares } \text { ex ante } \times \text { multiple, }\end{array}$ \\
\hline
\end{tabular}

where

Pill multiple $=($ Purchase multiple $\times$ Exercise multiple $)+1$,

Purchase multiple $=\frac{\text { Purchase value }}{\text { Exercise price }}$ and

Exercise multiple $=\frac{\text { Exercise price }}{\text { Future stock price }}$.

Because the number of outstanding shares is exogenous to the problem, our attention is necessarily focused on the trigger percentage and pill multiple. The nonbidder shares vary inversely with the trigger and directly with the pill multiple. As defined above, the pill multiple is composed of the purchase multiple (the dollars of value obtained per dollar of exercise) and the exercise multiple (the dollars to be placed at exercise per dollar of future stock price). The virtue of looking at the pill multiple (and hence the total dilutive effect of the pill) this way is that it allows an analyst to consider the effects of specific design assumptions. The courts, for instance, have shown great interest in the reasonableness of the pill's terms, specifically the trigger percentage and exercise multiple.

The effect of these two key drivers in our scenario can be illustrated in a sensitivity analysis of the cost of the pill to the bidder (Table 1 , line 23 , total costs imposed on the raider divided by expected future stock price). Consider how this figure varies with changes in the assumptions underlying the scenario (focusing on other criteria would reveal the same insights, so for simplicity, we restrict our attention to this one line of the model).

Table 2 considers two assumptions: the trigger percentage (varying from 10 to 49 percent) and the purchase multiple, or ratio of the value obtained to 


\section{TABLE 2}

Sensitivity Analysis: Costs Imposed by Pill on Raider as a Percent of Target's Future Market Value Ex Ante, by Trigger Percentage and Purchase Multiple

\begin{tabular}{clllll}
\multirow{2}{*}{$\begin{array}{c}\text { Trigger } \\
\text { Percentage }\end{array}$} & \multicolumn{5}{c}{ Purchase Multiple } \\
\cline { 2 - 6 } & 1.0 & 1.5 & 2.0 & 2.5 & 3.0 \\
10 & $270 \%$ & $275 \%$ & $278 \%$ & $280 \%$ & $282 \%$ \\
15 & 255 & 263 & 268 & 271 & 273 \\
20 & 240 & 250 & 257 & 261 & 263 \\
30 & 210 & 225 & 234 & 240 & 245 \\
49 & 153 & 176 & 190 & 200 & 207 \\
\hline
\end{tabular}

the exercise price (varying from 1 to 3 times). In 1990, purchase multiples varied from 2 to 4 times, and trigger percentages appeared to be at about 10 percent. Table 2 reveals that the bidder's costs increase with increases in the purchase multiple and with decreases in the trigger percentage. With a 10 percent trigger and a purchase multiple of $3 \mathrm{X}$, the pill would require the bidder to pay 2.82 times the pretrigger value of the firm.

\section{TABLE 3}

Sensitivity Analysis: Costs Imposed by Pill on Raider as a Percent of Target's Future Market Value Ex Ante, by Trigger Percentage and Exercise Price Multiple

\begin{tabular}{cllllll} 
Trigger & \multicolumn{6}{c}{ Exercise Price Multiple } \\
\cline { 2 - 7 } \begin{tabular}{c} 
Percentage \\
\cline { 2 - 7 }
\end{tabular} & 1.5 & 2.0 & 2.5 & 3.0 & 3.5 & 4.0 \\
10 & $142 \%$ & $188 \%$ & $233 \%$ & $278 \%$ & $324 \%$ & $369 \%$ \\
15 & 138 & 182 & 225 & 268 & 310 & 353 \\
20 & 134 & 175 & 216 & 257 & 297 & 337 \\
30 & 125 & 162 & 198 & 234 & 270 & 305 \\
49 & 106 & 135 & 163 & 190 & 217 & 243
\end{tabular}


Table 3 tests the effect on market value of variations in the trigger percentage and the exercise price multiple, or ratio of the exercise price to the expected future stock price. The bidder's costs increase dramatically with increases in the exercise price multiple and, again, with decreases in the trigger percentage.

Table 4 tests the relative importance of the two multiples and suggests that the bidder's costs are much more sensitive to variations in the exercise price multiple than to variations in the purchase multiple. The attention the courts and practitioners have paid to the reasonableness of the pill's purchase multiple (as opposed to exercise multiple) seems inconsistent with the actual economic effects of these pill features.

\section{TABLE 4}

\section{Sensitivity Analysis: Costs Imposed by Pill on Raider as a Percent of Target's Future Market Value Ex Ante, by Purchase Multiple and Exercise Price Multiple}

\begin{tabular}{lllllll} 
Purchase & \multicolumn{6}{c}{ Exercise Price Multiple } \\
\cline { 2 - 4 } & 1.5 & 2.0 & 2.5 & 3.0 & 3.5 & 4.0 \\
1.5 & $129 \%$ & $169 \%$ & $210 \%$ & $250 \%$ & $291 \%$ & $331 \%$ \\
2.0 & 134 & 175 & 216 & 257 & 297 & 337 \\
2.5 & 138 & 179 & 220 & 261 & 301 & 341 \\
3.0 & 141 & 182 & 223 & 263 & 304 & 344 \\
3.5 & 143 & 184 & 225 & 266 & 306 & 346 \\
4.0 & 145 & 186 & 227 & 267 & 308 & 348
\end{tabular}

This illustration affords a number of insights. First, over a wide range of structural assumptions, the pill is extremely costly to hostile bidders. Second, the cost is imposed through the economic dilution in the value of the shares currently held by the bidder and, more significantly, through the cost to acquire more shares. Third, the structural feature that seems to matter most is the exercise price multiple of the pill, although the effect of this feature interacts significantly with the effects of the trigger percentage and the purchase multiple. 


\section{Types of Pills}

In reality, the pill, in its brief life, has evolved rapidly into many forms-in contrast to the simple pill modeled in the preceding section. This evolutionary process was stimulated by judicial action and the increasingly sophisticated tactics of bidders. (Illustrations of plans and a history of court cases involving the pill are presented in Appendix 1.)

The earliest version of the pill, the convertible preferred stock dividend plan, was first adopted by El Paso Company in response to a tender offer by Burlington Northern in 1982 and has figured subsequently in the defenses of Lenox, Inc., ENSTAR Corporation, and Bell \& Howell Company in 1982. Under the El Paso plan, the common stockholder received convertible preferred stock carrying a higher-than-usual dividend. This feature would have the effect of discouraging conversion, absent a takeover bid, but the conversion price would be set at a level to encourage conversion should a bid appear-in effect, a flip-in provision. These plans also provided the shareholder (other than the bidder) with the right to "put" the stock back to the company if the bidder crossed a 20 percent threshold. This provision would have the effect of exhausting the target's assets and making the takeover less attractive. If the shareholder declined to convert into target shares or to put the preferred stock back to the target, this preferred stock automatically carried the same conversion rights into the stock of the bidder-in effect, a flip-over provision.

A slightly different version-the fair value plan, "put" rights plan, or note purchase rights plan-grants common stockholders the right to put their shares to the company after a triggering event, in return for cash or securities (for example, debt or preferred stock). This type of plan was used by Revlon and by AMF in their famous defenses. (See Appendix 1 for more discussion of these cases.) The key point of contention about this form of pill is whether firms can discriminate among shareholders in repurchasing or exchanging shares. Some court decisions suggest that this discrimination is permissible (Unocal, Revlon). The Securities and Exchange Commission (SEC), however, in responding to Unocal, adopted the "All-Holders Rule" (14(d) (10) (1)) requiring self-tenders to be open to all of an issuer's stockholders. Subsequently, in 1986 litigation over Allied Stores' put-rights pill, the SEC argued that the terms of the pill were subject to this new rule. The rule effectively quashed this pill.

The supervoting rights preferred stock dividend plan provides stockholders with a new issue of preferred stock containing disproportionately higher voting 
rights and the right of conversion into common stock. Subsequent to the appearance of this pill, the SEC promulgated rule $19 \mathrm{c}-4$, which prohibited disenfranchisement of the voting rights of shareholders and thereby prevented disproportionate voting schemes. The national exchanges also adopted "one share/one vote" rules having the same effect.

The time-phased voting plan grants a greater number of votes to long-term stockholders than to short-term holders, after a triggering event. Rule $19 \mathrm{c}-4$ also disabled this type of plan.

The share purchase rights plan is the type adopted by most corporations. Under this plan, each share receives a distribution of one right, or warrant, entitling the shareholder to buy shares of the target's common stock at an exercise price reflecting the "long-term" value of the company's common stock. These rights do not trade separately until triggered. No shareholder vote is required to issue these rights; the rights issuance does not affect earnings per share (EPS), capitalization, or trading of shares, and is not immediately taxable. ${ }^{3}$ These plans typically bundle two rights: a fiip-over right (right to purchase the bidder's shares), triggered when the bidder announces an offer for more than the threshold percentage; and a flip-in right (right to purchase target shares), triggered when the bidder actually obtains more than the threshold percentage of shares.

The legality of rights purchase plans containing only flip-over rights is in little doubt. The flip-in right, however, has been held to violate state corporation laws barring discrimination against shareholders within a security class (the basis on which the New York Supreme Court in 1988 forced Irving Trust to redeem its pill). Since then, six states-Ohio (1987), Wisconsin (1987), Hawaii (1988), Pennsylvania (1988), Florida (1988), and New York (1989)— have amended their corporate laws to permit discrimination among shareholders by means of a poison pill.

An important feature of the typical rights purchase plan is the board of directors' right of pill redemption, a provision allowing the company to buy back a pill's share purchase rights at a nominal cost (a few cents per right) any

${ }^{3}$ In Revenue Ruling 90-11, the Internal Revenue Service ruled that adoption of a typical shareholder rights plan does not constitute a dividend to shareholders or a taxable event under U.S. law (although it is a dividend under state law). The inference is that until a pill is triggered, the rights do not have value separately from the associated stock. 
time before the bidder crosses the threshold. The purpose of the redemption provision is to give the board flexibility to be able to respond to a hostile bidder who chooses to negotiate. One of the important points of controversy is the set of conditions under which the board may be compelled to redeem the pill. In general, the courts have permitted directors not to redeem pills if the tender offer is coercive (for example, two-tiered) ${ }^{4}$ if the tender offer is inadequate, even if for cash; ${ }^{5}$ or to permit exploration of alternatives or orderly auction of the company. ${ }^{6}$ The courts have forced redemption when the pill appears to interfere with shareholder choice at the end of an auction ${ }^{7}$ or when the pill is used as a last-ditch attempt to develop alternatives. ${ }^{8}$ (See Block and Pitt 1990 for a discussion of redemption issues.)

The adverse person plan is a pill with an ambiguous trigger-the directors retain the power to trigger the plan if they determine that an "adverse person" has bought a material number of shares.

The suicide or people plan was announced by Borden Company in 1989. In it, the 25 top managers of the company agree to resign en masse if shareholders do not receive "fair value" in a takeover and if any one of the 25 managers is fired or demoted. In this case, fair value was to be estimated either as the present value of the firm, plus 50 percent of any synergies, or as a cash offer accepted by 85 percent of disinterested stockholders.

The proxy pill provides shareholders the opportunity to vote in response to a hostile tender offer, in effect introducing a proxy-solicitation element into the pill. This option is available to a bidder provided that (1) the bidder furnishes a fairness opinion from an investment banker; (2) the bidder pays one-half of the costs of the vote or meeting; and (3) the bidder owns a nominal number of shares (for instance, 1 percent or less) (Burrough and Cohen 1987).

${ }^{4}$ See Desent Partners, L.P. v. USG Corp., 686 F. Supp. 1289 (ND Ill. 1988).

${ }^{5}$ See Damon Corp. v. Nomad Acquisition Corp., Fed. Sec. L. Rep. (CCH) 94,041 (D. Mass Sept. 20, 1988), and BNS, Inc. v. Koppers Ca., 683 F. Supp., 458 (D. Del. 1988).

${ }^{6}$ See CRTF Corp. v. Federated Department Stores, Inc., 683 F. Supp., 422 (S.D.N.Y. 1988) and MAI Basic Four, Inc. v. Prime Computer, Inc., Fed Sec. L. Rep. 94,179 (Del. Ch. Dec. 20, 1988).

${ }^{7}$ See Mills Acquisition Co. v. Macmillan, Inc., Fed. Sec. L. Rep. 94,071 (Del. Ch., Oct. 17, 1988).

${ }^{8}$ See City Capital Associates Ltd. Partnership v. Interco, Inc., Fed. Sec. L. Rep. 94,084 (Del. Ch. Nov. 1, 1988) and Grand Metropolitan PLC v. Pillsbury Co., Fed. Sec. L. Rep. 94,104 (Del. Ch. Dec. 16, 1988). 
The proxy element was introduced in 1987 as a response to judicial challenges to the basic pill and was adopted in pills by MCA, Santa Fe Southern Pacific Corporation, and Texaco.

The debt pill or put plan gives investors in a target firm's fixed-income securities the right to demand redemption of the securities if the issuer undergoes a material change, for example, in control or creditworthiness. This pill has been issued by CBS, Phillips Petroleum, Carson Pirie Scott, Sperry, Transco Energy, and W.R. Grace. The Delaware court struck down the debt-put that Revlon used in its defense against Pantry Pride in 1985. Other versions of the debt pill (see, for instance, covenants in debt issues by Harris Corporation and William Companies in 1988) specify as triggers more than half a dozen types of corporate restructurings that might result in a bond downgrading. Most often, this put is issued in defensive recapitalizations, which may explain why it is not widely used: adopting the pill would require issuance of debt.

The instant recapitalization pill triggers an automatic leveraged recapitalization of the company through a swap of notes for common stock. For instance, Cenergy Corporation adopted a plan in 1987 triggering a swap of one common share for $\$ 11$ face value of 15.25 percent subordinated notes if any person acquired 45 percent of the firm's stock.

The value assurance plan commits the firm to pay a preestablished dividend-even if the firm has to liquidate to do so-if by a certain date the firm's common stock does not exceed a target price level. If a hostile change of control occurs, the dividend is immediately payable or convertible into shares of common stock. Mayflower Group adopted this plan in 1986. This plan is the most radical of the pills because it positively commits the target firm to the delivery of value. Unlike other pills, the value assurance plan carries a number of disadvantages: the right is immediately taxable; the liability must be reflected on the balance sheet and could affect the calculation of EPS; the company becomes vulnerable to stock market downturns (or, conversely, an upturn would inadvertently relieve the company of its commitment); and the stock-value target might be interpreted as a minimum acquisition price, implicitly putting the company into play.

To place these various types of plans in some perspective, Ryngaert (1988) categorized the pills according to their deterrent effects on bidder behavior. 
The original pills and preferred stock plans were designed to deter two-tiered offers and freezeouts by making the second stage of a takeover prohibitively expensive. In general, flip-over plans deter mergers, asset sales, and self-dealing action by the bidder. Typically, these plans flip upon merger or asset sale, making these actions prohibitively expensive. They do not prevent an effective change of control, however. ${ }^{9}$ In general, flip-in plans are designed to deter any but all-cash tender offers. Finally, back-end plans, voting plans, and some flip-in plans aim to deter any substantial equity acquisition.

${ }^{9}$ Crown-Zellerbach was nominally protected by a flip-over plan that would trigger upon a merger attempt. Sir James Goldsmith, the bidder, skirted this pill by simply acquiring enough shares to control the board but not consummating a merger. 


\section{Impact of the Pill on Shareholder Welfare}

Much of the controversy about the poison pill revolves around the question of the harm or benefit the pill may cause the target firm's own shareholders. A pill might affect share prices in four ways: by signaling the latent value of the firm if restructured, by affecting the probability that the latent value will be realized (for instance, through capital market discipline), by anticipating a wealth transfer in the event that the pill is triggered, and by empowering incumbent management to bargain more effectively and thus to extract a higher price from a buyer. ${ }^{1}$ The likely direction and magnitude of the pill's effect on stock price is difficult to predict because of the unusual interplay of the four effects.

\section{Framework for Assessing Value Effects}

Ruback (1988) has suggested that the wealth effects of all takeover defenses can be understood in terms of the following model:

$\begin{array}{ll}\text { Market } \\ \text { value of }=\begin{array}{l}\text { Market value } \\ \text { with current } \\ \text { the firm } \\ \text { managers and } \\ \text { policies }\end{array}\end{array}+\left(\begin{array}{ll}\text { Probability } & \begin{array}{l}\text { Change in } \\ \text { value from } \\ \text { of change in } \times \\ \text { managers and } \\ \text { change in } \\ \text { molicies }\end{array} \\ \text { managers and } \\ \text { policies }\end{array}\right)$

\footnotetext{
${ }^{1}$ Berkovitch and Khanna (1990) have discussed how discriminatory value-reducing defensive strategies, which make a takeover more difficult and expensive for some bidders than for others, may enable incumbent management to get a higher price for the firm. For these strategies to be effective, they must discriminate among potential bidders and be expensive to redeem. Berkovitch and Khanna argue that poison pills as a class of anti-takeover defense fail on both counts.
} 
For instance, the signaling, deterrent, and empowerment effects of the pill affect investor welfare through the second term of this equation. To the extent that the pill signals higher latent value in the firm, the signaling effect will be positive. If the pill enables managers to extract higher prices, the empowerment effect should be positive. To the extent that the pill deters change, the effect of the pill will be negative. ${ }^{2}$

To compound the complexity of the pill, these effects are likely to be interdependent. For instance, the more deterrent the pill, (1) the lower the probability of change; (2) probably, the higher the potential wealth transfer (offset by a lower probability of that wealth transfer); and (3) possibly, the more optimistic the signal of potential value. Also, the more optimistic the signal, the higher the probability of change and the greater the value of the purchase right.

In short, whether the pill should have a positive or negative effect on share prices is difficult to say ex ante without knowing more about the relative magnitudes of the four basic effects and their interactions. This conclusion has three implications for empirical research. First, the pill may have no material effect, the positive and negative effects having washed each other out. Second, a negative tendency in the results must indicate a lowering of investor expectations of cash flows resulting from deterrence. Third, a positive tendency suggests that empowerment, expected wealth transfer, and restructuring benefits predominate over any effect on the probability of takeover.

\section{Empirical Evidence on Poison Pill Adoptions}

Examination of the results of several studies indicates that the effect of poison pill adoptions on share prices is basically negative, consistent with the view that the stringent deterrence of the pill overwhelms the signaling or potential wealth transfer effects. The controversy surrounding the use of poison pills is so intense, however, that a review of these research findings is in order.

\footnotetext{
${ }^{2}$ Ruback's general model might be augmented by a third term for specific analysis of poison pills. That term would reflect the value of the share purchase right per se. Intuitively, this term accounts for the possiblility of realizing the benefits of the wealth transfer illustrated in lines 13 and 16 of Table 1 . Even if the probability of such a transfer is very small, the value of this third term must be positive. Stated another way, a poison pill is an option, and options are always valuable (even if they are deeply out of the money). For simplicity, and because this third effect is probably not material, it will not be analyzed formally here.
} 


\section{The Georgeson Studies: A Critique of Methodology}

Georgeson \& Company, a proxy-solicitation firm usually serving defenders in takeover battles, published two studies that seem to suggest that the effect of pills on stock price is positive.

The first of Georgeson's studies considered percentage changes in stock price for targets of hostile tender offers, in cases in which the target ultimately experienced a change in control between January 1, 1986, and October 19, 1987 (Georgeson \& Company, Inc. 1988a). The sample comprised 48 firms (limited to firms of at least $\$ 100$ million in market value), and the study compared 27 firms that had pills in place with 21 firms that did not. For all the firms in the sample, a percentage change in stock price was calculated from the time of initiation of the hostilities to consummation of the takeover. The results of this study, shown in Table 5, Part A, indicate that gains were larger for companies with pills than for those without.

The second of Georgeson's studies used a sample of 100 firms randomly selected from 405 firms that adopted poison pills between July 1984 and September 1987 (Georgeson \& Company, Inc. 1988b). It also matched the pill firms with a control sample of nonpill firms selected for similarity to the pill firms in industry and size. Georgeson estimated percentage changes in stock price for these firms for fixed calendar periods from December 1985 to September 1987. Again, the study reported larger gains for companies with pills than without (see Table 5, Part B).

The conclusions of Georgeson's first study were supported by an enhanced study performed by Donald Margotta (1988), using essentially the same sample but calculating cumulative adjusted returns (CARs) for the pill and nonpill firms. ${ }^{3}$ Margotta's results are shown in Table 5, Part C.

The first Georgeson study raised strong criticisms from the United Shareholders Association (USA). The Association called the study "seriously flawed and misleading" (USA, unpublished report, April 5, 1988). USA obtained assessments of the study from six economists, who faulted it on various

\footnotetext{
${ }^{3}$ Margotta's improvements were to "check the data" and to use cumulative adjusted returns (CARs) instead of simple holding period returns. CARs are the total returns to a firm's stockholders (that is, including dividends and changes in stock price), adjusted for movements in the entire market and cumulated over some observation period. Margotta estimated his CARs using an equally weighted average of retums to all firms listed on the AMEX and NYSE. The CAR is widely used in financial economics as a measure of shareholder welfare.
} 


\section{TABLE 5}

\section{Evidence on the Stock Price Effects of Poison Pills}

Study

A. Georgeson \& Company I (1988a)

Gross change in stock price

Change, net-of-market

B. Georgeson \& Company II (1988b)

Gross change in stock price

Gross change for subsample with no confounding events

C. Margotta (1988)

Change in cumulated adjusted rate of return for period:

$$
\begin{aligned}
& -120,+23 \\
& -5,0 \\
& +1,+23
\end{aligned}
$$

D. Analysis Group (1988)

Stock price change, prepill

Stock price change, postpill
Firms

with Pills

$+78.5 \%$

$+52.7$

$+54.8$

$+49.3$

$+42.1$

$+23.3$

$+26.0$

$+10.7$

$+26.0$

$+2.3$

$+45.8$

$+27.8$

$+28.1$
Firms

without Pills

$+56.9 \%$

$+\mathbf{3 1 . 3}$

$+45.2$

$+43.5$

* Days before $(-)$ and after $(+)$ change of control.

grounds: selection bias (selecting a sample in such a way as to generate desired results); measurement bias (measuring an effect in such a way as to obscure actual losses); failure to correct for confounding effects, which might generate gains but be unrelated to the pill; making strong conclusions while ignoring other evidence to the contrary; and answering only part of the wealth effect problem (whether the pill produces higher takeover prices) and ignoring the potentially more significant effect of deterrence. ${ }^{4}$ USA also pointed out

\footnotetext{
${ }^{4}$ The specific criticisms were that the study offered no analysis of the negative effects poison pills have on shareholders in deterring takeover attempts; did not mention the decline in share value when companies use pills to defeat above-market bids; did not explain the criteria for selection of the firms in the sample; used too long a time frame (six months) to assess the effect of the pill on share value; did not evaluate the prebid performance of the companies with pills, which may have been undervalued because of poor management; and failed to evaluate evidence that adoption of pills reduces share prices.
} 
that the poison pill's inventor, Martin Lipton, had helped prepare the study, which cast doubt on its objectivity (Heard 1988, p. 34).

A critical reanalysis of the Georgeson sample by Analysis Group, Inc. (1988) reached the opposite conclusion to Georgeson's. The analysis used the same sample but measured stock price performance during two time periods (prepill and postpill), rather than Georgeson's fixed period of observation. The issue here is the possible confounding of stimulus (takeover rumors that might cause managers to adopt poison pills and that might cause the stock price to rise) with response (adoption of the pill). For instance, if pill adoption is a defensive response, then attributing the stock price appreciation to the pill before the pill is even adopted is inappropriate. The proper period of comparison is following the pill's adoption, not before.

The Analysis Group study found that much of the gain for pill companies actually occurred before the adoption of the pill and that afterward, the experiences of the two samples were similar (see Table 5, Part D).

The study suggested that much of the preadoption gain was attributable to rumors or anticipation of takeover; the pill was not in force at the time and could not have influenced share price. Comparing periods when the pill was in force revealed no significant influence.

The study went on to observe that more takeovers occur among samples of nonpill companies than among pill adopters, consistent with a significant deterrent effect of the pill. The conclusion was, "Pills are neutral or harmful to shareholders.... There is no sound empirical evidence suggesting that pills are in shareholders' interests."

\section{Event Studies of Poison Pill Adoptions}

The controversy about the Georgeson studies illustrates the difficulty in mounting a rigorous study of the wealth effects of poison pills. Event studies of poison pill adoptions surmount the measurement problems that surfaced in the criticism of the Georgeson studies. By focusing on the date of adoption, rather than the takeover episode, these studies are better able to isolate the effect of deterrence. The exclusion of observations with confounding events and the focus on a narrow window of time help sanitize the findings from confounding effects. Often, pills are adopted during hostile control contests, during which time stock returns are volatile and affected by many news items, not just the pill announcement. 
Four event studies of pill adoption have been published. Jarrell and Poulsen (1987) considered a sample of 37 firms announcing adoption of the pill; Ryngaert (1988) studied a sample of 380 firms announcing pills between 1982 and 1986; Malatesta and Walkling (1988) examined a sample of 132 firms announcing pills between December 1982 and March 1986; and Strong and Meyer (1990) examined a sample of 128 firms. ${ }^{5}$ Generally, these studies report a negative tendency in the stock price response at the event dates.

The findings of the first three of these studies are summarized in Table 6 . The Jarrell-Poulsen results reveal the importance of confounding events, such as an ongoing hostile takeover attempt, and of takeover speculation in estimating the effect of pill adoptions on stock price. For the 12 firms with no takeover speculation or confounding events, the effect of pill adoption is nil. For all other subsamples, however, the effect is significantly negative.

Ryngaert (1988), using the largest sample of all, reported results consistent with the other event studies. He argued that the insignificant return for firms with no confounding events and not subject to takeover speculation is attributable to the impact of two offsetting effects: the deterrence effect, which would produce negative returns, and the information effect, which would be associated with positive returns. Ryngaert observed that,

When firms become actual or rumored takeover targets shortly after the adoption of a poison pill, some of that activity is anticipated (or is triggered) at the time of the pill announcement. ... This suggests that poison pill announcement returns do convey some information about the firm's standing as a takeover candidate. (p. 400)

Ryngaert also examined the returns to shareholders of firms with pills that successfully deterred a takeover attempt. He found that in the six months following the defeat of the attempt, the target firms' share values declined 14.42 percent on average (net of market).

Malatesta and Walkling (1988) found that the negative effect of pill adoption appears regardless of whether a confounding prior takeover bid had occurred. Also, apparently, the more prominent the source of publication

\footnotetext{
${ }^{5}$ For some of these studies, the relevant samples are sometimes smaller than the stated sample size because of the unavailability of data or the appearance of confounding events that would invalidate an observation.
} 


\section{TABLE 6}

\section{Evidence on the Wealth Effects of Poison Pills}

Study

A. Jarrell and Poulsen (1987)

Whole sample ( 37 firms)

Firms subject to takeover speculation (25)

Firms with no confounding events (32)

Firms subject to takeover speculation (20)

Firms not subject to takeover speculation (12) $\quad+0.10$
Two-Day Net-of-Market Return

$-0.93 \%$

$-1.42^{\star}$

$-1.46^{\star}$

$-2.39^{*}$

B. Ryngaent (1988)

Firms with no confounding events (283)

$-0.34$

Firms subject to takeover speculation (57) $-1.51^{*}$

Firms not subject to takeover speculation (221) $\quad-0.02$

C. Malatesta and Walkling (1988)

Whole sample (113 firms)

Adoption of pill announced in prominent

publication (73 firms)

$-1.324^{*}$

Takeover bid before adoption (12 firms)

$-2.300^{\star}$

No prior takeover bid (61 firms)

* Statistically significant.

Sources: Jarrell and Poulsen (1987), Ryngaert (1988), and Malatesta and Walkling (1988).

(prominence being either the Wall Street Journal or the New York Times), the worse the announcement effect. The authors reported that the average dollar loss was $\$ 21$ million for their entire sample of pill adopters (113 firms). For their subsample of adopters for which adoption was reported in a major newspaper, the average loss was $\$ 29$ million. They conclude that "Poison pill defenses appear to reduce stockholder wealth" (p. 373).

Strong and Meyer (1990) decompose their sample according to whether the firm endured a control change subsequent to pill adoption. Their results, summarized in Table 7, show how dramatically the presence or absence of a takeover threat can affect investors' returns at the announcement of pill adoption. During a control contest, the announcement of a pill is associated with a significant loss in wealth ( -2.06 percent) as opposed to an insignificant loss $(-0.45$ percent $)$ in other circumstances. 


\section{TABLE 7}

\section{Wealth Effects of Poison Pills, by Control Change Experience}

\begin{tabular}{lcc} 
& \multicolumn{2}{c}{ Change in Shareholder Returns (CAR) } \\
\cline { 2 - 3 } & $\begin{array}{l}\text { Firms experiencing } \\
\text { a control change within } \\
\text { six months of adopting } \\
\text { period before (-) and }\end{array}$ & $\begin{array}{l}\text { Firms not experiencing } \\
\text { a control change within } \\
\text { six months of adopting } \\
\text { pill (34 firms) }\end{array}$ \\
-6 to pill adoption -3 months & $-36.70 \%^{*}$ & $-2.39 \%^{*}$ \\
-3 to -1 months & $-2.26^{*}$ & -1.41 \\
-1 month to -1 day & $+2.73^{*}$ & +0.87 \\
-1 to 0 days & $-2.06^{*}$ & -0.45 \\
+1 to +30 days or & & -0.73 \\
control change & $+6.94^{*}$ & \\
& & \\
patistically significant. & &
\end{tabular}

Source: Derived from Strong and Meyer (1990)

These four studies support the following conclusions about the wealth effects of poison pill adoptions:

- Adoption of the pill tends to have a negative effect on shareholder wealth.

- The negative effect is pronounced and significant in cases in which takeover speculation has occurred.

- In cases with no takeover speculation, the negative effect is insignificant, which is consistent with an offsetting information effect of the pill.

\section{Empirical Evidence on the Deterrent Effectiveness of the Pill}

The evidence seems to indicate that adoption of poison pills is costly to shareholders. Does the pill actually deliver deterrence in return for the costs? Ryngaert (1988) examined a sample of 29 firms with poison pills in place that received unsolicited tender offers and a sample of 76 firms not using pills that also received such offers. His results are presented in Table 8 . The firms with pills had a significantly higher probability of remaining independent. Ryngaert also noted that the data did not support the assertion that pills are more effective than other takeover defenses in stimulating increased bids. 


\section{TABLE 8}

\section{Evidence on the Deterrent Effectiveness of the Pill}

\section{Result}

Firm defeated all bids

Firm succumbed after receiving consideration above original offer

Firm succumbed to initial bid or other change of control

Sample total (29 firms)
Firms

with pills

$31.0 \%$

51.8

17.2

$100.0 \%$
Firms

without pills

$15.8 \%$

68.4

15.8

$100.0 \%$

Source: Derived from Ryngaert (1988)

\section{Comparative Effects of "Shark Repellent" Defenses}

Anti-takeover amendments to a corporate charter, commonly known as "shark repellants," are important alternatives to the poison pill defense. The percentage of publicly listed firms with some shark repellent in place is even higher than the percentage with poison pills. According to a survey taken at the end of 1989 by the Investor Responsibility Research Center, more than half of all firms have staggered board elections, one-third have fair-price provisions, one-quarter limit the use of consent solicitations, and one-fifth restrict petitions for special shareholder meetings (Mergers and Acquisitions 1990, p. 20). The effect of these amendments is to put conditions on and restrict the transfer of managerial control by altering a firm's voting practices. The main forms of these amendments are classified boards, supermajority provisions, fair-price amendments, and authorization to issue preferred stock.

Several studies present evidence that adopting a shark repellent has little effect on shareholder returns. DeAngelo and Rice (1983) studied the adoption of anti-takeover amendments between 1971 and 1979 and found insignificantly negative returns (about 1 percent). Linn and McConnell (1983) studied a larger sample, 475 firms announcing shark repellent amendments between 1960 and 1980, and found significantly positive returns (1.48 percent, at the date of board approval). Jarrell and Poulsen (1987) studied 649 firms proposing anti-takeover amendments and reported insignificantly negative returns at the announcement date but significantly negative returns for a period from 20 days before to 10 days after the announcement $(-1.25$ percent). They noted 
that the wider event window may be more appropriate because boards of directors meet an average of 27 trading days before the mailing of proxy statements, raising the possibility of leakage of information. McWilliams (1990) studied the stock price effects for 325 firms adopting anti-takeover amendments from 1980 to 1984 and partitioned the announcement-day returns by insider share ownership. The announcement-day returns were significantly negative for firms in which insiders owned 10 percent or less of the firm's shares; the announcement effect was insignificantly negative for the other firms in the sample.

In evaluating the comparative effects of various types of anti-takeover defenses, Ruback (1988) concluded that,

... defenses which do not give managers veto power and do not destroy assets, such as anti-takeover corporate charter changes, are probably not harmful. These defenses may cause bidders to restructure offers. They may result in slightly higher offer prices. Their major cost is that the defenses will reduce the benefit from being an acquiring firm and thereby reduce takeover activity. However, there is no evidence that the frequency of takeovers had been reduced by anti-takeover corporate charter amendments. (p. 65)

As defenses that do give managers veto power, Ruback cited dual-class recapitalizations and the poison pill. Destruction of assets refers to the sale of assets at below-market value or the acquisition of assets at above-market value simply to thwart a takeover.

Takeover defenses that require the participation of shareholders in the defense of the firm appear to have little effect on shareholders' welfare, in contrast to the poison pill, which grants incumbent managers and the board veto power over a merger decision (through the decision to redeem the pill).

\section{Profile of Companies Adopting Pills}

Given the adverse value effects of poison pill adoption, what kinds of firms adopt the pill? Some general characteristics emerge: a recent history of financial underperformance, greater insider influence in corporate governance than for other firms, and smaller insider holdings.

Malatesta and Walkling (1988) compared 122 firms adopting a pill with firms, matched by industry, that did not adopt a pill. They found that poison pill adopters tend to be less profitable than the average firm in their respective 
industries. For the year prior and the three years prior to adoption, operating margins of pill adopters were insignificantly different from other firms in their industries, but net profit margin, return on total capital, and return on net worth were significantly lower than the average for their industries.

Strong and Meyer (1990) compared the results for 146 pill adopters with matched firms in their respective industries and found significantly lower price/earnings ratios and significantly higher extraordinary items and tax loss carryforwards. As compared to their prior year, pill adopters have worsening stock prices, rising leverage, and rising trading volume. The authors characterize those firms adopting poison pills as being "in the midst of substantial restructuring."

Malatesta and Walkling's analysis also reveals that among poison pill adopters, insiders, officers, and directors held an average of 9.39 percent of total share soutstanding; among the nonpill comparison firms, the average was 23.12 percent. This difference was highly significant statistically. Strong and Meyer found that shareholder rights firms have a significantly higher percentage of inside board members, significantly less management ownership of shares, a greater probability of substantial family ownership or employee ownership, and larger institutional ownership. The latter findings suggest a pattern of strong ownership preferences among the boards of directors and managements of these firms.

Reflecting on the governance profile of pill adopters, Malatesta and Walkling wrote,

Despite the loss of stockholder wealth that ensues, rational managers will adopt poison pill defenses if they believe that the benefits they receive exceed the costs they bear. We argue that the costs and benefits are directly related to the amount of stock managers hold in their own firms. The costs of adopting a defense are an increasing function of managerial ownership, while the benefits are a decreasing function. Our analysis therefore implies that managers who adopt poison pill defenses are likely to hold relatively small amounts of stock in their own firms. The data bear out this prediction. . . . Managerial interests appear to be important determinants of the decision to adopt a poison pill defense. (p. 374)

\section{Conclusions and Implications from Research}

Formal research results are rarely unanimous and always invite further work; larger samples, fresher data, and more insightful tests may shed new light on 
the effects of the poison pill. Given the sample sizes and the corroborative nature of the various existing studies, however, a reasonable inference is that the pill exhibits the following tendencies:

- The effect of poison pill adoption on the firm's stock price around the date of announcement is negative. Although the magnitude of the loss seems small (say, about 1 percent), the large size of the typical pill adopter implies that in absolute terms the associated loss runs into many millions of dollars. The direction and magnitude of the effect will vary, however, depending on the context of the announcement, the presence of other confounding events, the prominence of the announcement, and the time period of study.

- Often, the pill is adopted after a period of financial underperformance and in the context of takeover rumors or in response to an unsolicited tender offer.

- The pill appears to be effective in deterring announced and outstanding bids. The most significant question-the pill's deterrence of unannounced bidders-is probably untestable from public data.

- The pill does not appear to extract higher payments from bidders as compared to payments received by firms without pills. 


\section{Simulating the Effect of a Poison Pill}

The review of the mechanics of the pill and the evidence on how it affects shareholder wealth leave us with a large unfilled appetite in two respects. First, adoption of the pill may deter unsolicited bidders, but whether it does or not is simply unobservable. Recall that the only research on deterrence is Ryngaert's analysis of the rate of defeat of target firms that had received offers. Our larger interest is in targets that might have received offers but did not because of the pill. As the review of the pill's mechanics shows (see Chapter 2), the pill is likely to be highly deterrent across a wide range of trigger levels, purchase multiples, and exercise multiples. Situations could exist, however, in which the raider's gains from restructuring would more than offset the economic dilution imposed by the pill; in these situations, the gains would justify an attack regardless of dilution. Given this possibility, the efficacy of the pill as a deterrent warrants further consideration.

Second, one of the common defenses of the pill is that it buys time for current management to maximize share value through its own operating strategy. To know whether management's strategy is truly dominant (as opposed to the raider's strategy) requires a forecast of performance under management's and the raider's strategies. Such forecasts, again, are simply unobservable by researchers. A reasonable hypothesis is that the value impact of the pill will be affected by (1) the existence at date of pill adoption of any difference in the value of the firm under the two strategies, and (2) the degree of uncertainty about the value of the firm in the future under the two strategies. The different present values of competing operating policies should be the critical factor in assessing the appropriateness of a pill for a specific firm and for fashionable legislative and judicial rules regarding the pill. 


\section{The Hypothetical Case and Simulation Model}

Although actual data are not available to pursue these issues, simulation of a hypothetical case can offer a number of valuable insights. The simulation technique used here allows uncertainty to be modeled explicitly so as to test the effect of different levels of uncertainty about the pill.

In this hypothetical situation, a firm's stock prices are projected into the future, as they would be under current management's and under the raider's operating strategies. The simulation assumes that stock prices under the incumbent's and raider's strategies follow a random walk through an observation period 120 months long. Appendix 3 describes the simulation in more detail.

The raider in the hypothetical case is aiming to exploit any value disparity between market prices and restructuring values by bidding for the firm's shares, if the disparity is positive enough to meet the raider's target return on investment. At the end of 10 years, if the firm is not successfully taken over, the hypothetical shareholder sells his or her shares for the then-current market price. If the firm is taken over, the shareholder receives the bidder's offer price in the bidding month. Either way, these payments are discounted to their present value and compared.

Running the model over 100 trials produced a probability distribution of the difference between present values under the pill and nonpill scenarios. Given the controlled nature of the simulation, the difference, if any, would have to be interpreted as the value effect of the poison pill:

Value effect of the pill = PVCF (pill in place) - PVCF (no pill),

where PVCF equals the present value of cash flows. "Pill in place" means that incumbent management can continue implementing its strategy; shareholders "cash out" at month 120 . "No pill" means that contests for control are permitted; shareholders receive a premium payment from the raider at the time of the raid.

A measure of deterrence, also calculated over 100 trials, is the difference in the number of instances in which the raider's target return on investment would have been met even if a pill were in place.

$$
\text { Deterrence Index }=\frac{E[\text { Raids (no pill) }]-E[\text { Raids (pill) }]}{E[\text { Raids }(\text { no pill) })} \text {, }
$$


where

$$
\begin{aligned}
E[\text { Raids (pill) }]= & \begin{array}{l}
\text { The average number of opportunities to raid } \\
\text { over the } 120 \text {-month period, with a pill in place. }
\end{array} \\
E \text { [Raids (no pill) }]= & \begin{array}{l}
\text { The average number of opportunities to raid } \\
\text { over the } 120 \text {-month period, without a pill in place. }
\end{array}
\end{aligned}
$$

This index value will vary between 0 and 1 , and a value of 1 indicates that the pill would have deterred the raider 100 percent of the time.

\section{Estimated Deterrence of the Pill}

Deterrence indexes were estimated for poison pills that were configured to be relatively (a) weak, (b) moderate, and (c) strong relative to actual pills configured in early 1990 . The weak pill featured a trigger percentage of 49 percent of outstanding shares, an exercise multiple of $2 \mathrm{X}$, and a purchase multiple of $2 \mathrm{X}$. The moderate pill featured a 20 percent trigger, an exercise multiple of $3 \mathrm{X}$, and a purchase multiple of $2 \mathrm{X}$. The strong pill featured a 10 percent trigger, a $4 \mathrm{X}$ exercise multiple, and a $2 \mathrm{X}$ purchase multiple. The estimates were also classified according to whether initially (a) the current value of the shares and restructuring value were equivalent or (b) the restructuring value exceeded the current value by one-third. The results of this simulation do not warrant detailing here. Regardless of the type of pill and regardless of an immediate restructuring opportunity, in 100 percent of the cases in which the raider would have found an attack otherwise economically attractive, the pill deterred the attack.

The main conclusion of this analysis is that the pill is an absolute deterrent; in virtually no instance would a raider acting rationally attack in the face of a pill. The chance that a large potential restructuring gain would induce an attack is virtually nil. The raider's only recourse is to press directors, shareholders, and the courts to rescind the pill.

\section{Simulating the Value Effect of the Pill}

Probabilistic simulation affords an opportunity to estimate the effect of pill adoption on stock price without the kinds of confounding effects found in studies of actual data. Many scenarios were simulated to estimate the value effect and test its sensitivity. All of these scenarios were variations on the following base case: the pill is moderately strong, as defined in the preceding 
section; initially, the current stock price and restructuring values of the firm are identical; and the standard deviations in stock price and restructuring values are moderate ( 9.24 percent a month, or 32 percent annually, which is about the mode of volatilities for stocks with exchange-traded options). ${ }^{1}$

The distribution of effects of the adoption of this pill are shown in Figure 1. For 100 trials, the average difference in the present values of the two control strategies is $-\$ 8.57$ a share, or roughly a third of the ex ante share price of the hypothetical firm. The distribution has a standard deviation of $\$ 7.45$, and it is skewed to the left of the mode.

The distribution is dominated by the 16 percent of the outcomes in which the result was no change in stock price-that is, cases in which the pill made no material difference. In 9 percent of the cases, the effect of the pill was positive. $^{2}$ About one-quarter of the time, then, the effect of the pill is nonnegative, which seems to support pill proponents. The other three-quarters of the outcomes are negative and large, however, skewing the distribution. The negative mean suggests that, across many pills, shareholder wealth will decline. The reason for the loss is the deterrent effect of the pill and foregone opportunity to sell to a raider at a higher price than the then-prevailing share price.

\section{Varying the Risk Assumption}

The value effect of uncertainty about the future may be tested by varying the monthly standard deviation of stock price and restructuring value from the base case, which offered a 9.24 percent monthly deviation. Figures 2 and 3 present the results of simulations with 18.76 percent and 4.33 percent monthly deviations. These monthly deviations may be annualized to 65 and 15 percent standard deviations, respectively - a range that encompasses the majority of

${ }^{1}$ Cox and Rubinstein (1985), p. 358, reported that for a sample of 377 stocks with exchange-traded options between 1980 and 1984, about 40 percent of the total had volatilities in the range between 30 and 39 percent, the volatility decile with the greatest frequency.

\footnotetext{
${ }^{2}$ The effect of the pill is positive in those cases in which it makes sense for stockholders to disregard the raider's bid and instead hang on to their shares in the expectation of receiving a much higher flow of cash later on (that is, from the incumbent's strategy). These cases illustrate the argument of pill proponents that the pill permits managers to execute their strategies for creating value over the long term. Given the time value of money, the expected future payment must be quite large for this strategy to be attractive.
} 
Figure 1

Stock Price Effects of a Moderate Pill with "At-the-Money" Restructuring Option and 9.24 Percent Monthly Deviation

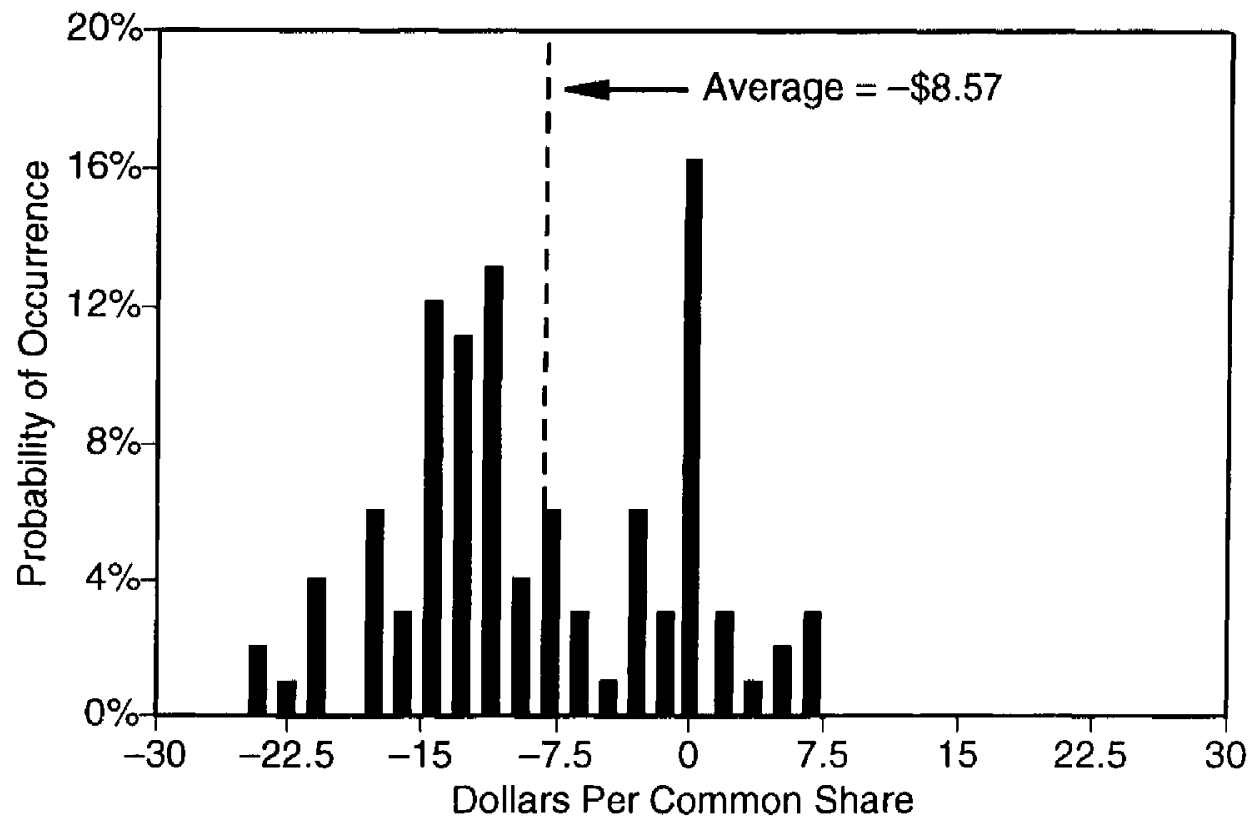

publicly traded common stocks. ${ }^{3}$ The distributions in both figures are remarkably different from the base-case assumption of 9.24 percent.

In Figure 2, the effect of the pill on share price is worse, $-\$ 10.13$ (standard deviation of $\$ 7.57$ ), as compared with $-\$ 8.57$ in the base case. Intuitively, the reason is that higher risk is attended by a higher probability that the restructuring value will exceed the existing stock price-that is, that the restructuring option will be in the money. Hence, the left-hand (negative) tail of the distribution here shows a much higher frequency of loss than in the base case. Also, the incidence of nonnegative outcomes is now 15 percent of the cases rather than 25 percent.

${ }^{3}$ Cox and Rubinstein (1985) reported that, between the years 1980 and 1984,97 percent of publicly listed stocks with exchange-traded options had annualized volatilities between 10 and 60 percent. 
Figure 2

\section{Value of Moderate Pill Assuming 18.76 Percent Monthly Deviation}

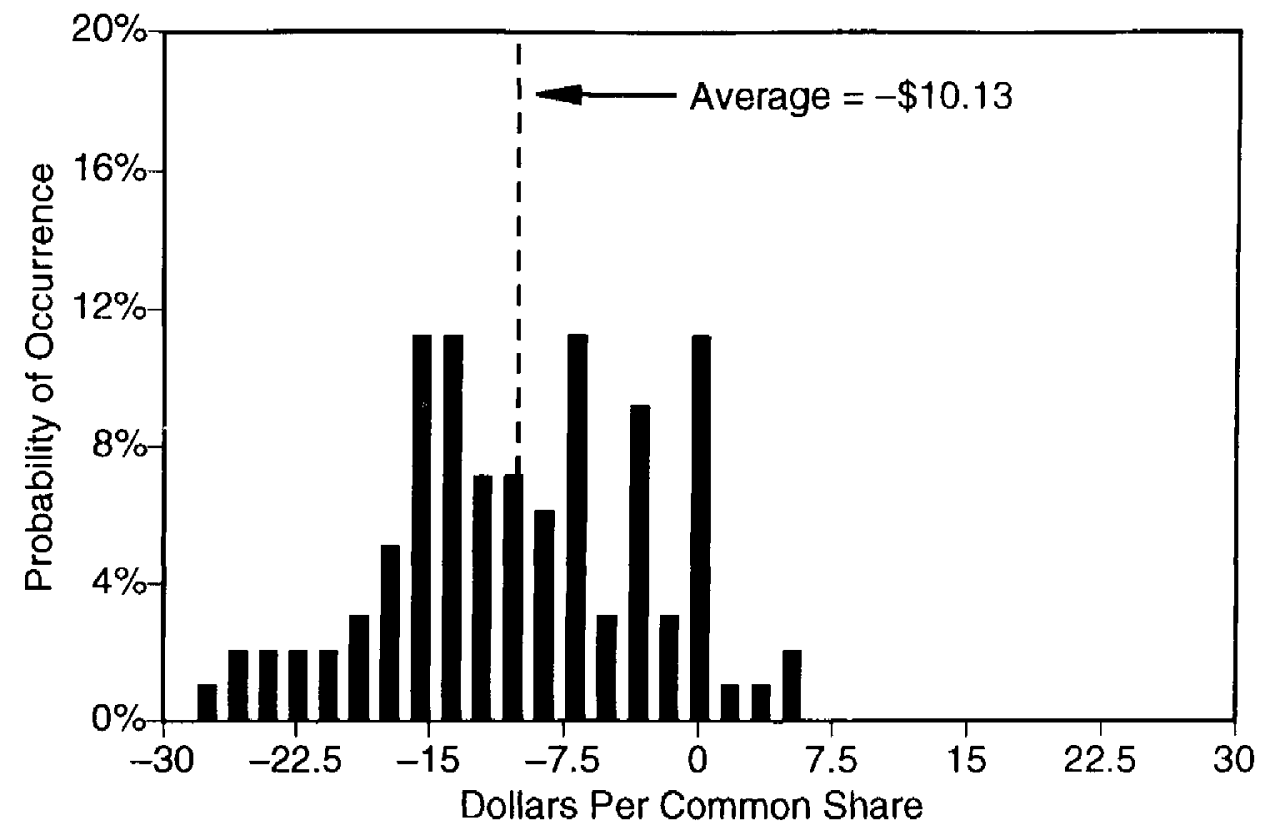

With lower risk (Figure 3 ), the effect of the pill is less adverse, an average effect of $-\$ 5.44$ (standard deviation of $\$ 5.23$ ) as opposed to the $-\$ 8.57$ of the base case. The distribution is still negatively skewed, but the left-hand tail is overshadowed by the high incidence (32 percent) of zero differences. In this case, the lower monthly deviations in values may decrease the chance that the restructuring option would be deep enough in the money to motivate the raider to attack.

The important implication of these simulated results is that the value effect of the pill is inversely related to risk. To the extent that uncertainty can be characterized by the measure of periodic deviation, pill adoptions will destroy shareholder wealth in direct proportion to uncertainty about the firm's future. 


\section{Figure 3}

\section{Value of Moderate Pill Assuming 4.33 Percent Monthly Deviation}

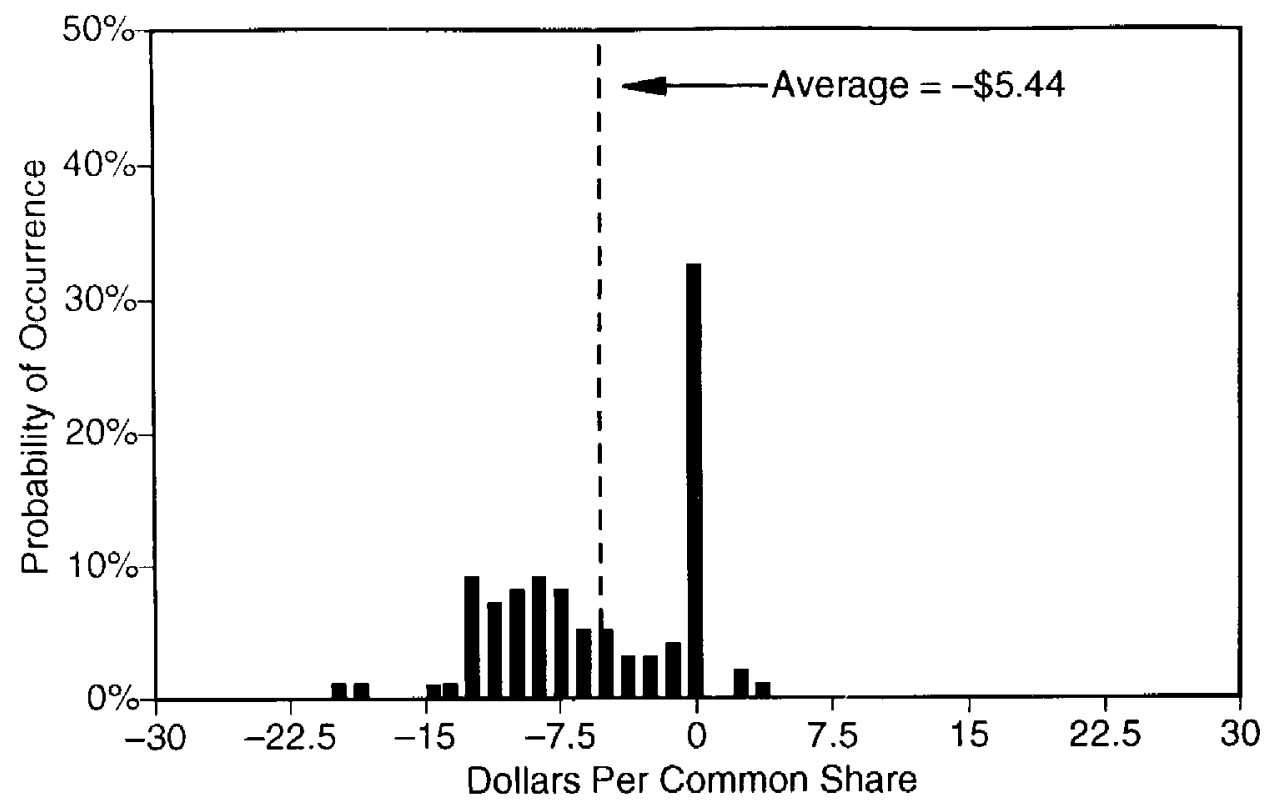

\section{Varying the Initial Restructuring Gains}

The base case assumed that initially the stock price equaled the value of shares if the firm were to be restructured by the raider-that is, the option to restructure was at the money. Many firms, however, adopt poison pills under the assumption that the raider's option to restructure is in the money-that is, that the restructuring value is greater than the initial stock price. In other cases, managers contend that they are already pursuing the operating strategy having the highest value for the firm, and thus the raider's restructuring option is out of the money-that is, the stock price exceeds the value of the firm if restructured.

Figures 4 and 5 present variations on the base case, holding constant all assumptions except the restructuring gains. In generating the simulated results in Figure 4, the restructuring option is initially deep in the money-the 
stock price is initially set at $\$ 25$, while the value if restructured is initially $\$ 33.33$. In the simulated results in Figure 5, the restructuring option is initially deep out of the money-the value if restructured is only $\$ 16.66$.

In the context of large positive restructuring gains ex ante (Figure 4), the adverse effect of the poison pill is huge: $-\$ 14.91$ a share (standard deviation of $\$ 5.47)$. This distribution distinguishes itself by having the lowest proportion of nonnegative outcomes, 6 percent; the shareholders lose consistently because in virtually all cases, the raider would like to bid but cannot. Therefore, the shareholders forego the opportunity to sell to the raider at prices higher than they can obtain under management's current strategy.

In the context of an out-of-the-money restructuring option (Figure 5), the effect of the pill is negative and relatively small, $-\$ 2.35$ (standard deviation of $\$ 4.21$ ), but it still is significantly less than zero. The distribution is dominated

Figure 4

Moderate Pill in Which Restructuring

Is "In the Money"

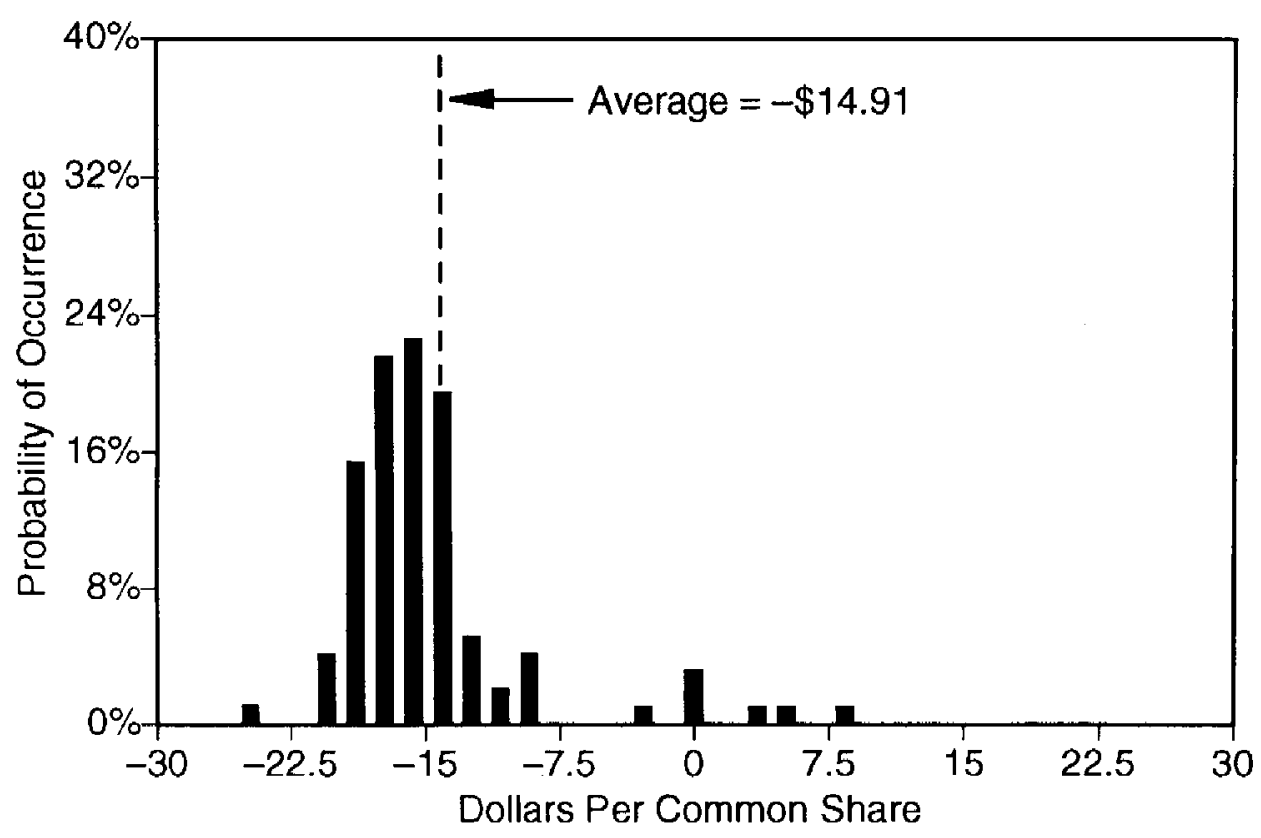




\section{Figure 5}

\section{Moderate Pill in Which Restructuring \\ Is "Out of the Money"}

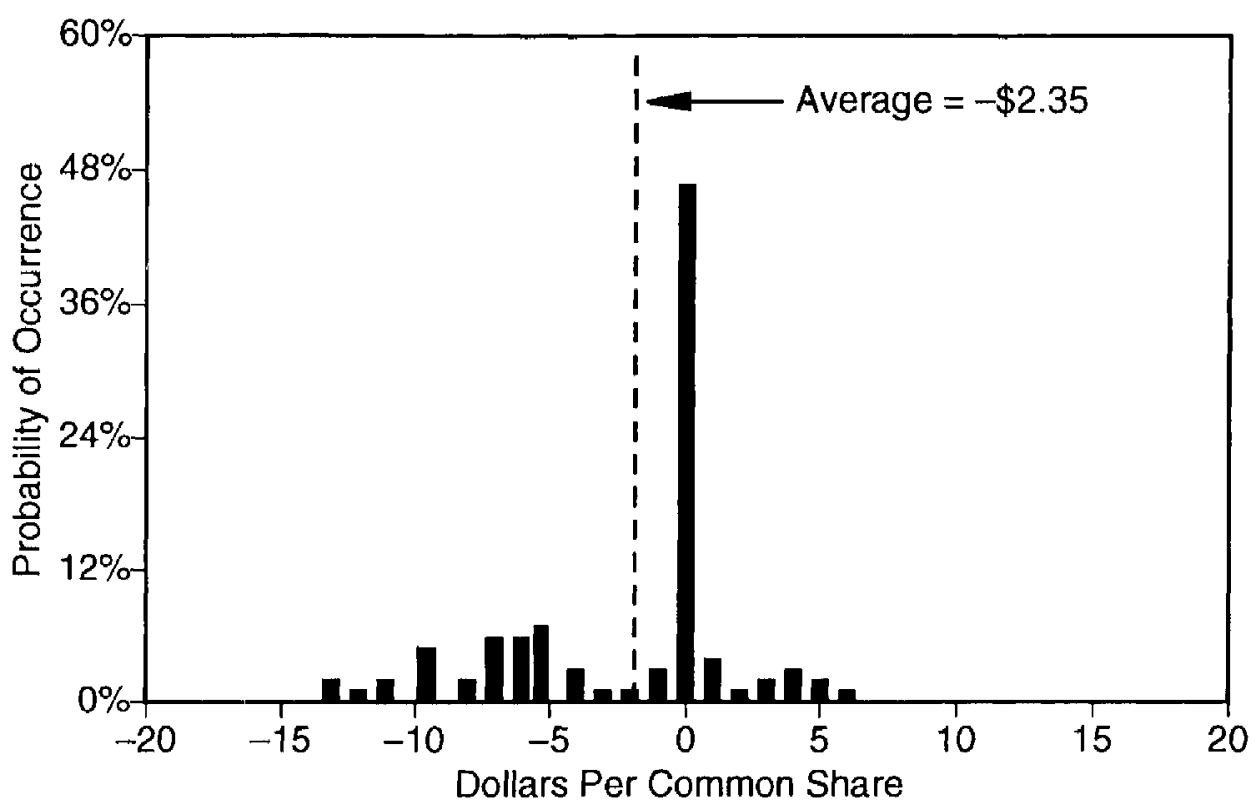

by cases with a zero dollar outcome for shareholders- 48 percent of the cases-consistent with the much lower attractiveness of this situation to the raider. Thirteen percent of the distribution has positive outcomes for shareholders, and 39 percent has negative outcomes.

The main conclusion of this analysis is that restructuring gains are inversely related to the effect of the poison pill on shareholders' wealth. I.arge positive restructuring gains are associated with large negative wealth effects. Zero restructuring gains today are associated with moderately negative wealth effects. Negative restructuring gains today are associated with small negative wealth effects.

An obvious question from these results is, why does the effect of the pill not turn positive when the restructuring today would create losses for shareholders? The answer is that the pill not only forecloses restructuring today 
but also in the future, at which time restructuring by a raider might result in wealth creation for shareholders.

\section{Wealth Effects of Different Pill Structures}

The empirical evidence on the pill's deterrence effects reveals that even very "weak" pills are highly deterrent. Do variations in the structure of a pill affect shareholders' wealth? The answer from the research reported here is no. Simulation of the change in shareholder wealth using the pill structures described previously produced quite similar mean values for the per-share reduction in stock prices. The reduction for the strong pill is $\$ 8.37$ (standard deviation of $\$ 7.00$ ); for the moderate pill, $\$ 8.57$ ( $\$ 7.45$ ); and for the weak pill, $\$ 8.50(\$ 6.68)$. The difference among these results is not statistically significant.

On reflection, these results should not be surprising. The value effect of the pill derives from its deterrent effect on raiders. If a wide variety of pills is about equally deterrent, the wealth effects should not vary much either.

\section{Conclusions from the Simulation}

The simulation analysis sheds light on effects of the pill that are difficult to measure in conventional empirical research. First, the pill is completely deterrent. It dilutes the raider's potential returns from restructuring so severely that in no case is the raider motivated to bid.

Second, the value impact of the pill is more negative the greater the uncertainty about the target firm's future. This is because with more uncertainty comes the larger probability that the returns from future restructuring will be positive. With a highly deterrent pill, the shareholders cannot claim the restructuring gains, which imposes an opportunity cost on them.

Third, the value impact of the pill is more negative the larger the immediate opportunities for restructuring. Of the effects tested, the restructuring "option" is by far the most significant determinant of the value impact of a pill.

Fourth, the specific structure of the pill does not seem to make much difference to shareholders' wealth. This finding is arresting because a great deal of judicial effort is spent trying to determine the fairness of specific pill structures. 


\section{Survey of the Current Controversy}

Controversy about the poison pill has taken many forms and has been joined in many different settings. Appendix 1, which summarizes the landmark court cases on the poison pill, conveys some of the reach of this controversy into federal and state courtrooms, but the controversy has also entered federal and state legislatures.

\section{Federal and State Legislation}

In 1987, Congress considered prohibitions on "abusive" defense tactics, including poison pills that had not been approved by shareholders. ${ }^{1}$ In 1988 , the Senate briefly considered an amendment to ban poison pills unless they were explicitly approved by shareholders. ${ }^{2}$

At the same time, six states-Ohio (1987), Wisconsin (1987), Hawaii (1988), Pennsylvania (1988), Florida (1989), and New York (1989)-have taken the opposite direction, opposing takeovers through antitrust actions and enacting statutes explicitly permitting poison pill defenses and other defensive

\footnotetext{
${ }^{1}$ House Resolution 2172, referred to as the Dingell-Markey Bill, was introduced into the House Energy and Commerce Committee in April 1987 but was never reported out.

${ }^{2}$ Senators Byrd and Proxmire sponsored an anti-takeover bill (S. 1323) that would require greater disclosure of attempts to buy control of a company and also would put limits on some raider tactics. Senators Armstrong, Gramm, Metzenbaum, and Shelby devised a series of shareholders' rights amendments to the bill. A ban on golden parachutes passed the Senate by a vote of 98 to 1 . Proxmire attempted to kill an amendment to ban poison pills by a tactic of tabling the amendment; the motion to table failed by 40 to 57 . Byrd and Proxmire pulled the bill from the floor of the Senate before votes could be taken on other amendments to ban greenmail payments and specify procedures for counting ballots in elections and charter amendments. See Cranford (1988), pp. 1717-18.
} 
tactics (see Lewis 1990). The legislative momentum for state anti-takeover regulation began in 1985, when the Indiana legislature passed "control-share" laws in response to the Belzberg family's hostile takeover attempt of Arvin Industries. A "control-share" statute grants an unsolicited bidder voting rights only if the remaining shareholders vote by a majority of shares to grant such voting rights. By the spring of 1990, 21 states had enacted control-share legislation. Academic research suggests that the shareholder wealth effects of state anti-takeover legislation are nil (Pugh and Jahera 1990) to negative (Ryngaert and Netter 1987, Schumann 1987, and Karpoff and Malatesta 1990).

\section{Institutional Activism}

Perhaps the most interesting development in the controversy is the rising tide of shareholder resolutions at corporate annual meetings calling for recision of the pill. These resolutions have been sponsored by institutional investors, the leaders of which have been four large public pension funds: The California Public Employees' Retirement System (CalPERS), the College Retirement Equities Fund (CREF), the California State Teachers' Retirement System (CalSTRS), and the State of Wisconsin Investment Board (SWIB). Trustees of pension funds associated with the United Brotherhood of Carpenters and Joiners of America also have filed anti-poison pill shareholder proposals. In Canada, Caisse de Depot et Placement, the large Quebec Pension Plan investment firm, opposes the poison pill and has confronted several corporations on the issue (Gibbens 1989). The pension trustees' activism is significant because of their funds' huge equity interest in corporations. Martin Lipton has observed, "If the institutions act together in combination with the raiders, they will have unrestrained power to topple any corporation in America" (Michel and Shaked 1986, p. 241).

A 1988 survey of 127 institutions revealed that 63 percent generally voted for proposals to redeem a poison pill (Bergin 1988). Those most supportive of redemption were public pension funds ( 80 percent) and private pension funds ( 84 percent). Those least supportive were universities, foundations, and church groups ( 60 percent) and investment managers (51 percent).

The record of voting on the recision of poison pills, presented in Table 9 , reveals that shareholder proposals are a relatively recent phenomenon. A surge of proposals marked 1987, although they were supported by a relatively low percentage of shareholder votes. In 1988, the institutional proponents of recision sponsored fewer resolutions, concentrating on cases with a higher 
probability of success. The result was higher average numbers of supporting votes but few successes over all. Meanwhile, the record also shows that management proposals to approve "blank check" preferred stock authorizations (regarded as precursors of, or supporting, poison pill plans) continued to meet with little opposition.

The scattered successes of this institutional activism are noteworthy. In May 1988, 49 percent of all shares (61.2 percent of the shares that were voted) of Santa Fe Southern Pacific Corporation were voted in support of a resolution to rescind the pill. The resolution had been offered by a small group of trainmen, Olympia \& York Developments, and Henley Group (the two firms had expressed an interest in acquiring Santa Fe). Under SEC regulations, such shareholder resolutions are not binding on boards of directors. Thus, management of Santa Fe vowed not to rescind the pill. The chairman of Henley Group responded that management's attitude was similar to that of Boss Tweed a century before: "As long as I count the votes, what are you going to do about it?" (quoted in Valente 1988a).

Other successes included a majority vote to rescind at Rorer Group and a 47.7 percent approval of a rescision resolution at USAir. After meeting privately with representatives of CalPERS, management of Aluminum Company of America agreed to redeem the plan or submit it to a shareholder vote by 1991. Texaco, after meetings with CalPERS and the Pennsylvania Public School Employees' Retirement System, announced its intention to terminate its poison pill by April 1989 as part of a restructuring.

\section{TABLE 9}

\section{Institutional Activism, 1984-89}

\begin{tabular}{|c|c|c|c|c|c|c|}
\hline & 1984 & 1985 & 1986 & 1987 & 1988 & 1989 \\
\hline \multicolumn{7}{|l|}{ Shareholder proposals to rescind } \\
\hline poison pill plan (number) & 0 & 0 & 0 & 32 & 19 & 32 \\
\hline "Yes" votes (mean \%)" & 一 & - & - & 29.4 & 38.7 & 36.7 \\
\hline Management proposals to approv & & & & & & \\
\hline check preferred stock" (number) & 19 & 20 & 55 & 90 & 40 & \\
\hline “No" votes $(\operatorname{mean} \%)^{\star}$ & 8.6 & 11.2 & 10.4 & 14.4 & 19.5 & \\
\hline
\end{tabular}

* Excludes abstentions.

Source: Derived from Investor Responsibility Research Center (annual 1985-89). 
In the 1990 annual meeting season, shareholder plebiscites defeated poison pills at five companies and motivated one firm, Del. E. Webb Corporation, to rescind its shareholder rights plan. As a percentage of votes cast, anti-pill resolutions won at Webb (56.5 percent of the vote), Weyerhaeuser Company (54 percent), Lockheed Corporation (53.6 percent), Ryder System (53 percent), and K-Mart Corporation (50.7 percent). In September 1990, Lockheed's board voted to suspend the pill under the following conditions: (1) the bid must be a fully financed, all-cash offer for all shares; (2) owners of a majority of the shares outstanding (except the bidder's) must accept the bid; (3) the bidder must provide a written fairness opinion; (4) the bidder must commit to equal treatment of all shareholders on the same terms and price; and (5) the offer must remain open for at least 60 business days.

\section{The Fundamental Issues}

Thompson (1989) summarized the arguments supporting or opposing the pill as follows:

\section{Arguments in Support of the Pill:}

- Pills give boards the power to protect shareholders from coercive bidding tactics such as the two-tiered tender offer and the partial tender offer.

- Pills deter self-dealing transactions by large shareholders.

- Pills compel a bidder to negotiate the terms of a business combination with the board.

- Pills extract higher bid premiums from raiders (because shareholders are typically dispersed widely and unable to negotiate collectively).

- Pills do not change the firm structurally or affect its earning capacity-in this, they are better than other defenses such as restructurings, asset sales, or "scorched earth" strategies.

- Pills may help maximize shareholder wealth (most proponents point to the Georgeson studies).

Arguments Against the Pill:

- Pills transfer power from shareholders to directors-in particular, the power to consider unsolicited tender offers.

- Pills entrench management. 
- Pills chill all expressions of acquisition interest and preempt the market in corporate control.

- Pills decrease shareholder wealth.

- Pills are almost always adopted without shareholder approval.

The arguments on both sides tend to boil down to two fundamental issues of governance: fairness for all shareholders, and managerial and board discre tion.

\section{Fairness for All Shareholders}

One of the classic arguments against the pill is that it discriminates against certain shareholders - the raiders. In general, state corporation law has traditionally opposed schemes that would discriminate. Flip-over pills are generally judged to be acceptable, but flip-in pills often are not; several notable cases interpreting New York, New Jersey, and Colorado law have invalidated discriminatory pills. ${ }^{3}$ Thompson (1989) wrote,

These decisions rest on the principle that at least when shareholder approval has not been obtained, the state law in question does not permit discrimination among similarly situated shareholders. (p. 193)

State anti-takeover law is changing rapidly, however. Several states have amended the law to permit discriminatory pills. The Supreme Court has rejected federal intervention (via the supremacy and commerce clause challenges), ${ }^{4}$ which opens the way for passage of a flurry of control-share statutes and business-combination statutes. ${ }^{5}$

\section{Managerial and Board Discretion}

Figuring largely in the governance debate stimulated by the pill is the question of whether and to what extent boards of directors should preempt share-

\footnotetext{
${ }^{3}$ Asarco v. MRH Holmes a Count, Amalgamated Sugar v. NL Industries; and Bank of New York v. Irving Trust.

${ }^{4}$ Dynamics Corp. of America v. CTS Corp. (1988).

${ }^{5}$ Business-combination statutes limit the manner in which a successful bidder can exercise control over the acquired company. Specifically, they discourage "bust up" bids without the approval of the target's board. Decision making about the acceptability of a bid is vested in the board, not shareholders.
} 
holders in the choice of whether to sell their shares to a hostile bidder. Jensen (1987) commented,

Poison pill securities change fundamental aspects of the corporate rules of the game that govern the relationship between shareholders, managers, and the board of directors.... The right essentially restricts the alienability of the common stock by prohibiting shareholders from selling their shares without permission of the board, into a control transaction leading to merger at a price that involves a premium over market value ... (p. 26)

Litigation over the pill now focuses importantly on a board's decision to redeem the pill. The general pattern emerging from court decisions is that a board need not redeem a pill if the offer is coercive, the offer is inadequate, or the pill is being used to protect an auction process. ${ }^{6}$ The courts have found the pill to be impermissible, however, if the pill is used to forestall the conclusion of an auction or used to prolong the auction unnecessarily. The basic view appeared in the Interco decision.

To acknowledge that directors may employ the recent innovation of "poison pills" to deprive shareholders of the ability effectively to choose to accept a noncoercive offer, after the board has had a reasonable opportunity to explore or create alternatives, or attempt to negotiate on the shareholders' behalf, would, it seems to me, be so inconsistent with widely shared notions of appropriate corporate governance as to threaten to diminish the legitimacy and authority of our corporation law. ${ }^{7}$

In short, then, the debate over the legitimacy of the poison pill antitakeover defense becomes a lightning rod for a much larger debate: the legitimacy of the Anglo-American scheme of corporate governance.

The essence of the governance debate is apparent in the basic elements of disagreement between the two sides, which might be labeled "Capitalists" (see, for instance, Coates 1989, Gilson and Kraakman 1990, and Easterbrook and Fischel 1981) and "Managerialists" (see, for instance, Lipton and

${ }^{6}$ Coercive tender offers are characteristically two-tiered offers and partial tender offers. Augliera (1989) has argued that even all-cash/all-shares tender offers may be "coercive" if they are inadequate, timed opportunistically (for instance, in the midst of temporary financial adversity), or complex and possibly misleading.

${ }^{7}$ Delaware Chancery Court 1988, City Capital Associates v. Interco, Inc., 551 A. 2nd 787. 
Rosenblum 1990 and Lowenstein 1988). Table 10 summarizes and contrasts the views of the two sides.

At present, the drift of change in rulings, laws, and regulations seems to favor the managerialist perspective. Recent court decisions, such as in the Time-Warner case, legitimize the role of managers as the guardians of the firm's long-term best interests. Laws passed in Pennsylvania and Massachusetts in 1990 permit or require boards of directors to consider the welfare of other interested parties. As of late 1989, approximately 6 percent of all large, publicly traded corporations had corporate charter amendments that allowed directors to consider issues other than price, including community impact, environmental matters, employment, and future strategy.

\section{The Judicial and Legislative Trend}

The key question about the efficacy of the pill is whether it can withstand legal assault. In several prominent cases, target boards have been forced by the courts to redeem pills. ${ }^{8}$ In other prominent cases, the courts have not forced redemption. $^{9}$

The general pattern of the decisions in these cases suggests that courts will use at least three criteria in testing whether a corporation should redeem a pill: (1) whether the board was adequately informed in its decision to adopt the pill and in its selection of pill terms, (2) the reasonableness of the pill's trigger percentage and exercise price, and (3) the severity of discrimination among shareholders.

Yablon (1989) contended that this uncertainty about the legality of the pill tends to drive raiders and directors to the bargaining table, which is desirable. Hence, he argued against legislation that would clarify the legal standing of the pill.

\footnotetext{
${ }^{8}$ Southdown, Inc. v. Moore McCormack Resources, Inc. (1988), Nomad Acquisition Corp. v. Damon Corp. (1988), City Capital Associates v. Interco, Inc. (1988), Grand Metropolitan v. Pillsbury (1988), Dynamics Corp. of America v. CTS Corp. (1986), Amalgamated Sugar Co. v. NL Industries (1986-87), Topper Acquisition Corp. v. Emhart Corp. (1989).

${ }^{9}$ MAI v. Basic Four (1988), TW Services v. SWT Acquisition Corp. (1989), In Re Holly Farms Corp. Shareholders Litigation (1989), Kingsbridge Capital Group v. Dunkin Donuts, Inc. (1989), Bank of New York v. Irving Bank Corp. (1988), West Point-Pepperell v. Farley, Inc. (1988), and Amanda Acquisition Corp. v. Universal Foods (1989).
} 


\section{TABLE 10}

\section{Summary of the Governance Debate}

\begin{tabular}{|c|c|c|}
\hline & Capitalists & Managerialists \\
\hline Governance should: & $\begin{array}{l}\text { Ensure that actions of } \\
\text { managers and directors } \\
\text { accurately reflect wishes } \\
\text { of stockholders. Perfect } \\
\text { the process of drawing } \\
\text { contracts among } \\
\text { shareholders and managers. }\end{array}$ & $\begin{array}{l}\text { "Create a healthy, stable } \\
\text { economy through } \\
\text { successful business } \\
\text { operations." (Lipton) }\end{array}$ \\
\hline Corporations are: & $\begin{array}{l}\text { A creation of shareholders. } \\
\text { Private property. A nexus of } \\
\text { contracts among individual } \\
\text { participants. }\end{array}$ & $\begin{array}{l}\text { A creation of the state; } \\
\text { an entity separate from } \\
\text { the shareholders. To do } \\
\text { business is a privilege. } \\
\text { The corporation is a } \\
\text { common good; not really } \\
\text { private property in } \\
\text { traditional sense. }\end{array}$ \\
\hline Managers are: & $\begin{array}{l}\text { Agents of shareholders, } \\
\text { but also are self-interested; } \\
\text { need discipline. Separation of } \\
\text { ownership from control in the } \\
\text { modern corporation is the } \\
\text { major problem. }\end{array}$ & $\begin{array}{l}\text { Capable, well-meaning } \\
\text { people who will run the } \\
\text { tirm well if left alone. } \\
\text { Their interests should be } \\
\text { paramount. }\end{array}$ \\
\hline Stockholders are: & $\begin{array}{l}\text { Owners. Their interests } \\
\text { should be paramount. } \\
\text { Without the shareholders, } \\
\text { the corporation would not } \\
\text { exist. }\end{array}$ & $\begin{array}{l}\text { Just another stakeholder } \\
\text { group. Stockholders must } \\
\text { share claims with other } \\
\text { constituents such as } \\
\text { employees, customers, } \\
\text { suppliers, and the public. }\end{array}$ \\
\hline Stockholders own: & $\begin{array}{l}\text { The assets of the firm. } \\
\text { Can claim to be paid a } \\
\text { premium for corporate } \\
\text { control. }\end{array}$ & $\begin{array}{l}\text { Just shares of stock, } \\
\text { financial claims, not the } \\
\text { assets. Like "holding a } \\
\text { betting slip at a racetrack." } \\
\text { Deserve no premium for } \\
\text { corporate control. }\end{array}$ \\
\hline Hostile takeovers: & Useful discipline & $\begin{array}{l}\text { Destructive and inefficient } \\
\text { discipline. }\end{array}$ \\
\hline $\begin{array}{l}\text { Institutional } \\
\text { investors: }\end{array}$ & $\begin{array}{l}\text { Sophisticated. } \\
\text { Instruments of discipline. }\end{array}$ & $\begin{array}{l}\text { Short-term oriented. Not a } \\
\text { traditional proprietor-type } \\
\text { owner. }\end{array}$ \\
\hline $\begin{array}{l}\text { Some policies } \\
\text { advocated: }\end{array}$ & $\begin{array}{l}\text { Remove pills, other } \\
\text { defenses. Laissez-faire } \\
\text { corporate statutes. } \\
\text { Elect true outsider- } \\
\text { directors. Improve } \\
\text { proxy voting mechanism. }\end{array}$ & $\begin{array}{l}\text { Maximum discretion for } \\
\text { managers. Permit poison } \\
\text { pills. Permit long terms of } \\
\text { office for directors. Strive } \\
\text { for proprietor-type investors } \\
\text { such as Warren Buffet or } \\
\text { Japanese Keiretsu. }\end{array}$ \\
\hline
\end{tabular}


Attitudes about whether state legislatures should respond to the controversy over the pill depend fundamentally on perceptions of deficiencies in financial markets and of firm-specific contracting. Ribstein (1989) suggested that the path of regulation is not clearly better than nonregulation.

Even if the capital markets do not perfectly police corporate contract terms, legally imposed terms would not necessarily be better. Courts frequently lack expertise in corporate matters, the incentive to formulate optimal rules, and the resources to investigate complex matters of corporate policy. The behavior of political agents, including legislators, is subject to even greater agency problems than those that infect the judgment of corporate agents. Legislative and judicial rules also suffer from overgenerality and stasis: they apply equally to large numbers of firms and are relatively difficult to change. (p. 78)

Ribstein argued that it is too easy for legislative and judicial rules to exceed their reach. For instance, imposing broad fiduciary duty on the board and limiting the autonomy of shareholders to respond to bids would (1) create an incentive for managers to resist all takeovers, (2) expose the takeover process to greater judicial error, (3) raise the cost of litigation, (4) deter bids that would actually maximize welfare-simply because of the uncertainty about how the courts would apply the fiduciary duty rule in particular cases, (5) impose heavy burdens on shareholders who want to restrict directors' powers (for instance, via charter amendments), and (6) upset existing contracts among directors and their shareholders. 


\section{Conclusions}

From the standpoint of deterrence, the poison pill is virtually a sure thing. Rarely do innovations in corporate finance work as well as their proponents claim, but the simulation analysis here reveals that the pill is a highly effective deterrent. When faced with a pill, the raider's only recourse is to press directors, shareholders, or the courts to rescind it.

Strategic deterrence is always costly; it is never free. The cost to the aggressor is the increased price of aggression if deterrence succeeds partially or the lost opportunity if deterrence succeeds completely. The costs to the defender are the set-up cost of the deterrent and the cost of making good on the threat if the aggressor attacks. These costs are clearly manifest in geopolitics. In financial politics, the costs are more latent.

The key question about the pill is, Who pays the cost of the pill's deterrence-the bidder or the target? Proponents of the pill imply that it is the bidder: with the pill, fewer companies succumb to a raid, and those that succumb do so at a higher premium. In this view, the pill is essentially "free" to target firms. The empirical evidence and simulations do not bear out this reasoning: stock prices decline on adoption of the pill, targets with pills sell at about the same premiums as other firms, and share values of firms with pills will, on average, be lower than those of firms without pills. In short, the economic evidence suggests that the target shareholders pay for deterrence.

The cost of the pill's strategic deterrence should be weighed against expected benefits such as the flexibility for current managers to execute an existing or potential operating plan for the firm. Whether this plan is better than alternative plans (especially the raider's) should be the main point of analysis of the pill. In this regard, the value framework and simulation analysis reveal that an attractive alternative plan, such as a restructuring, that is deterred becomes a large opportunity cost to shareholders. 
The opportunity cost is difficult to assess because of uncertainty about the future. The simulation analysis suggests that this very uncertainty should be an element of a board's consideration. As uncertainty increases, the pill becomes more costly. With greater uncertainty comes the higher probability that the raider's alternative operating plan will be the higher-valued alternative and, thus, that the opportunity cost of deterrence will be higher.

Assessment of the pill's costs is relevant to securities analysts, as well as to managers and directors. Pill adoptions, or shareholder votes on motions to rescind pills, are obvious occasions on which to take the economic point of view this monograph suggests. The magnitude of the stock price discount imposed by the pill may be estimated using simulation analysis. But even casual analysis of the key determinants of the pill's discount can provide insight into the materiality of effect of this anti-takeover device.

Perhaps the most significant impact of the economic point of view is to reorient the thinking of decisionmakers away from the tactical issues of takeover defense and toward fundamentals such as maximizing the value of the firm. This view would say that the best takeover defense is a high stock price and that any other defense is perhaps a distraction.

The 16th century political realist, Machiavelli, reached the same conclusion in a somewhat different context. In considering the conditions under which fortresses would be helpful to rulers, he concluded that such defenses are not straightforwardly beneficial.

Fortresses, then, are either useful or not, according to circumstances: if they benefit you in one way, they injure you in another. This matter may be dealt with as follows: that the Prince who is more afraid of his own people than of foreigners should build fortresses; but one who is more afraid of foreigners than of his people should not consider constructing them. (The Prince)

The pill helps erect the corporate fortress of the late 20 th century. The appropriateness of the defense hinges fundamentally on an assessment of precisely who, in the eyes of management, is the hostile adversary. The proliferation of the pill implies that it is the shareholders themselves, not the raiders. 


\section{Appendix 1.}

\section{Evolution of the Poison Pill: Case History}

This appendix presents an overview of representative poison pills, with an emphasis on those pills that have come before major federal and state courts. ${ }^{1}$

\section{The First Poison Pills: Convertible Preferred Stock Dividends} Poison pills first appeared in 1982 as convertible preferred stock dividends designed to protect against partial and front-end-loaded tender offers. The goal of these plans was to encourage a potential acquirer to purchase 100 percent of the target company and to force the acquirer to pay the same price for each share acquired. Typically, a target corporation issued dividends in the form of preferred stock, convertible to common stock in the event of a partial or front-end-loaded tender offer, at a redemption price equal to the highest price paid by an acquirer during a given period of time. The effect of the conversion would be to make it more expensive for the acquirer to maintain his ownership position in the target company and to guarantee that, in the event of a later business combination, all target shareholders would receive the same price for their shares.

El Paso Company and Burlington Northern, Inc. In response to a tender offer by Burlington Northern in 1982, the El Paso Company announced the first poison pill, a convertible preferred stock dividend issue. Under the plan, for each 20 shares of El Paso common held, the company issued one share of new 8 percent cumulative preferred stock. Each share of the new preferred was immediately convertible into a share of El Paso common stock. Additionally, if any single entity acquired 25 percent of the company and did not within 10 days offer to acquire the remaining 75 percent at a share price at least as high as the highest price the acquirer paid to obtain any of the original 25 percent, then the new preferred shares were entitled to elect one-third of the El Paso directors. Despite El Paso's efforts, this first poison pill proved ineffective. The company capitulated in 1983 and accepted the terms of Burlington Northern's original offer.

\footnotetext{
${ }^{1}$ The factual accounts and discussion of the cases in this appendix are largely based on reports in the Wall Street Journal, on Lipton and Steinberger (1989), on Pitt et al. (1990), and on Lewkow and Groll (1990).
} 
Brown-Forman Distillers Corp. v. Lenox, Inc. [C.A. No. 83-2116 (D. N.J. June 20,1983$)$ ]. In June 1983, a federal district court upheld a convertible preferred stock dividend plan adopted by Lenox in response to a hostile tender offer by Brown-Forman. The plan entailed the issue of 1 share of convertible preferred for each 40 shares of Lenox common stock held. The preferred carried a redemption price of $\$ 500$ a share but could only be redeemed within 15 years by approval of 95 percent of the preferred holders. The pill also contained a flip-over measure that provided that in the event of merger between an acquirer and Lenox, the preferred would be convertible to common shares of the surviving company. The effect of such a conversion would dilute voting control in the acquiring company, a significant effect for the Brown family controlling Brown-Forman. Like the El Paso pill before it, the Lenox pill eventually proved ineffective in blocking a takeover, and Lenox finally recommended the Brown-Forman deal to its shareholders.

Following the experience of El Paso and Lenox, two additional companies, Bell \& Howell and ENSTAR, announced convertible preferred stock dividend plans. The Bell \& Howell plan was upheld by a Delaware court, which found that the issuance of convertible preferred stock was not a violation of Delaware corporation law. ${ }^{2}$ Similarly, a Delaware court determined that ENSTAR's convertible preferred stock dividend plan was a legitimate mechanism for protecting the company's shareholders. ${ }^{3}$ These early pills were only moderately successful in warding off hostile bidders, however, and designers of poison pills sought to develop new versions of this takeover defense.

\section{Share Purchase Rights Plans and Variations on the Theme}

Following on the lessons learned from convertible stock dividend plans, target corporations later adopted a more sophisticated approach-the share purchase rights plan. Under this approach, the target corporation issues to its shareholders "rights" to purchase, at a significant discount, stock of any corporation that acquires 100 percent of the target's stock in a business combination following a triggering event (flip-over provision). The triggering event is usually the acquisition by a potential acquirer of a given percent of the target's stock. Some rights include the option to purchase shares of the target

${ }^{2}$ National Education Corp. v. Bell \& Howell Co., C.A. No. 7278 (Del. Ch. August 25, 1983).

${ }^{3}$ Huffington v. ENSTAR Corp., C.A. No. 7543 (Del. Ch. April 25, 1984). 
at a similar discount upon the occurrence of the triggering event (flip-in provision). Included in the plan is a provision permitting the target's board of directors to redeem the rights (buy them back from the holders) at the nominal price. Share purchase rights plans are the most popular form of poison pill in effect today.

Moran v. Household International [500 A. 2d 1346 (Del. 1985)]. The current popularity of share purchase rights plans largely results from the endorsement of such plans provided by the Delaware Supreme Court in its 1985 decision in the Household International case.

Household International's directors had adopted a share purchase rights plan with several provisions. Holders of Household common stock were entitled to one right per share of common stock held. Each right entitled the holder to purchase discounted Household shares or discounted shares of an acquirer, upon the occurrence of certain triggering events. If a potential acquirer announced a tender offer for 30 percent or more of Household's shares, then a flip-in provision entitled rights holders to purchase $1 / 100$ share of new preferred stock for $\$ 100$. In this event, the board of directors could redeem the rights for $\$ 0.50$ per right. Alternatively, if anyone successfully acquired 20 percent or more of Household's shares, holders of the rights could purchase $1 / 100$ share of new preferred, and the board could not redeem the rights. Also under the plan, a flip-over provision stated that if a right was not exercised for preferred, and a later merger or consolidation occurred, the holder could exercise each right to purchase $\$ 200$ of the acquirer's common stock for $\$ 100$.

The Delaware Supreme Court upheld the Household plan, ruling that it warranted the protection of the Business Judgment Rule, which presumes that in making a business decision the directors of the corporation acted on an informed basis, in good faith, and in the honest belief that the action taken was in the best interest of the company.

The court applied the test it had set forth in its earlier decision, Unocal Corp. v. Mesa Petroleum Co. [493 A2d 946 (Del. 1985)], to determine whether, in the context of defensive tactics, the Business Judgment Rule should apply. That test requires: (1) that the board show that it had reasonable grounds for believing that a danger to corporate policy and effectiveness existed, demonstrated by the board's good faith and reasonable investigation; and (2) that the board show that the defensive mechanism was "reasonable in relation to the threat posed." In applying this test, the Unocal rule additionally provides 
that when a majority of a board consists of outside directors, then the board's decisions will be given even greater deference.

Applying the Unocal test, the Delaware Supreme Court upheld the Household share purchase rights plan. The court determined that the presence of two-tier and similar coercive takeover tactics in the market for corporations provided the Household board with a reasonable basis for its belief that a danger to corporate policy and effectiveness existed, even though at the time the board adopted the pill, Household was not subject to any hostile takeover activity. Also, the court found that the share purchase rights plan was a reasonable response to the threat posed, on the grounds that it did not strip stockholders of their right to receive tender offers and that it did not unduly restricit the ability of stockholders to wage a proxy battle.

Importantly, the court did not decide whether, in response to a tender offer, a decision not to redeem the rights in the Household plan would be justified under the Business Judgment Rule. Because no tender offer had been made to holders of Household shares, the court left this issue open, stating only that any decision not to redeem the rights would be subject to the same Unocal test that the court applied in this case. Subsequent cases have dealt with this issue.

Crown Zellerbach and Sir James Goldsmith. Crown Zellerbach was the first company to adopt a share purchase rights plan. The 1985 plan was substantially similar to that of Household International. Rights would be issued upon the acquisition by one entity of 20 percent of Crown Zellerbach. In the event of a later 100 percent acquisition of Crown Zellerbach, holders of rights could purchase shares of the merged entity at a 50 percent discount. Sir James Goldsmith initiated a tender offer for Crown Zellerbach stock on the condition that the company redeem the rights. Goldsmith abandoned the tender offer when the company refused to redeem the rights and instead acquired a majority of Crown Zellerbach stock through open market purchases and through a street sweep. Goldsmith proceeded to restructure the company but stopped short of the full 100 percent stock ownership necessary to trigger the discount purchase provision of the rights. Although the rights plan did not prevent Goldsmith from taking control of Crown Zellerbach, the plan did accomplish several other goals: it delayed by five months Goldsmith's takeover, it increased the board's bargaining power, it forced Goldsmith to abandon his tender offer, it protected minority shareholders from being squeezed out at Goldsmith's original price, and it resulted in shareholders receiving a 20 percent premium over Goldsmith's original acquisition price. 
Amalgamated Sugar Co. v. NL Industries [644 F. Supp. 1229 (S.D. N.Y. 1986), affirmed 825 F. 2d 634 (2d Cir.), cert. denied 484 U.S. 992 1987]. In 1986, NL Industries introduced a share purchase rights plan. Under the plan, one right was issued per share of NLIndustries common held on a given record date. The triggering event under the NL Industries plan was the acquisition of 20 percent or more of NL Industries common or a tender offer for 30 percent or more. A flip-in provision entitled rightsholders other than the acquirer to purchase NL Industries shares at one-half market price. The district court distinguished New Jersey law from that of Delaware by holding that the NL Industries rights plan was invalid. The court found that the plan appropriated shareholders' rights to receive tender offers and discriminated between shareholders of the same class of stock by excluding the acquirer from exercise of the rights.

Bank of New York v. Irving Bank Corporation [Nos. 5568, 5588 (N.Y. Sup. Ct. July 6, 1988), affirmed 143 A.D. 2d 1073 (1988)]. In May of 1988, Irving Bank adopted an amendment to its share purchase rights plan that added a 20 percent flip-in provision to the plan. The amendment was adopted in the midst of a battle for control of the company both by the Bank of New York and Banca Commerciale Italiana. Bank of New York challenged only the flip-in provision of the plan, claiming that the provision discriminated among holders of the same class of stock in violation of New York law. The court agreed and invalidated Irving's flip-in provision. In response to the court's decision, the New York legislature adopted a statute specifically permitting flip-in provisions.

CRTF Corp. v. Federated Department Stores [(1987-1988 Transfer Binder) Fed. Sec. L. Rep. (CCH) P93,680 at 98,114 (S.D. N.Y. March 18, 1988) ]. Federated's 1986 share purchase rights plan included a flip-in provision. The provision was to be triggered upon the acquisition of 30 percent of the company's shares, but it could be triggered upon acquisition of 15 percent of the company's shares if Federated's board found the acquirer to be an "adverse party." CRTF challenged Federated's plan in federal district court, applying Delaware law. The court found Federated's plan withstood the Business Judgment Rule test and that Federated could be allowed to use the plan to enhance the active bidding for the company from two potential acquirers, Macy's and CRTF.

Desert Partners v. USG [686 F. Supp. 1289 (N.D. Ill. 1988)]. Desert Partners challenged a share purchase rights plan adopted by USG on the 
grounds that the exercise price of the rights under the plan was unreasonably high in relation to the current market price of USG shares. The court, applying Delaware law, noted that the exercise price of rights under most rights plans is between 200 percent and 500 percent of the stock's market price. The court found USG's exercise price to be within this range and upheld USG's plan.

Harvard Industries, Inc. v. Tyson [Fed. Sec. L. Rep. (CCH) P93,064 at95,293 (E.D. Mich. November 25, 1986)]. Unlike the New York court in the Irving Bank case, a district court hearing the Harvard Industries litigation found that flip-in provisions of a share purchase rights plan discriminated among shareholders but did not discriminate among shares and was therefore permitted under Michigan law.

West Point-Pepperell v. Farley, Inc. [711 F. Supp. 1088 (N.D. Ga. 1988)]. Farley challenged a flip-in provision adopted by West Point-Pepperell in October 1987. The rights plan entitled shareholders of record to purchase $1 / 1000$ share of preferred stock for each share of common held. The rights were to become exercisable upon acquisition of 20 percent of the company's stock by an acquirer engaged in self-dealing transactions or upon the announcement of a tender offer for more than 30 percent of the company's shares. Upon either of these triggers, each right would entitle its holder to purchase a given number of West Point-Pepperell shares at one-half their market price.

In May 1988, Farley announced its intention to acquire 25 percent of West Point-Pepperell's shares. West Point-Pepperell's board responded by reducing the flip-in trigger point to 10 percent and by eliminating the requirement that the acquirer engage in self-dealing transactions. The board also added an exercise option permitting holders of rights (other than the acquirer) to exchange, without any further payment, each right for a share of common stock. The district court determined that the flip-in provision, as amended, violated Georgia law because it discriminated among shareholders of the same class of stock by diluting Farley's voting rights and equity position in the company.

The above cases are representative of the large number of share purchase rights plans that were announced following the decision in Household International. With respect to their flip-over provisions, these plans have been largely upheld in the courts, although, as the NL Industries and Irving Bank cases indicate, some courts have been reluctant to uphold flip-in provisions. Meanwhile, several companies have expanded on the original share purchase rights plan, developing plans that have been termed "second-generation" 
share purchase rights plans. These plans differ from the traditional plans only in their provision for a shareholder vote in response to a hostile acquirer's demand that rights be redeemed.

In 1987, MCA developed the first "second-generation" pill. The MCA plan contained both flip-in and flip-over provisions. If any acquirer obtained 20 percent of MCA common stock, then the flip-over provisions would entitle holders to purchase shares of the acquirer. This part of the MCA plan was in line with the flip-over provisions of traditional plans. The MCA flip-in provision, however, contained significant new features. First, although the flip-in rights would be triggered by a 20 percent acquisition, the board retained the power to reduce this triggering level if it deemed that such a reduction was desirable.

Most importantly, if a potential all-shares/all-cash acquirer with an offer to buy wished to challenge the MCA board's refusal to redeem the rights, then the acquirer could call a special shareholder's meeting to consider the acquirer's request. A vote to redeem the rights by a simple majority of the shareholders would override the board's refusal to redeem the rights.

The acquirer would not have the right to call a special meeting of shareholders if the acquirer owned more than 1 percent of the target's shares or if the acquirer had owned more than 1 percent in the prior 12 months and had announced an intent to acquire control of the target. Additionally, the potential acquirer would be required to have financing commitments, to present an opinion by a recognized investment bank that the offer was fair, and to pay for one-half of the costs of the special shareholders' meeting.

Other companies, notably the Santa Fe Southern Pacific Corporation and Texaco, have adopted variations of the second-generation share purchase rights plan. Although the plans differ in their provisions, they have in common a provision calling for shareholder approval of either the issue or the redemption of share purchase rights. By allowing for a shareholder vote on either issue or redemption, these plans hope to withstand the scrutiny of courts concerned about a board's duty to act in the best interest of its shareholders.

With a provision for a shareholder vote on the issue or redemption of share purchase rights, several companies have ended up in the courts, not on the issue of the legality of the rights themselves but on the legality of a board's refusal to redeem rights when an acquirer with an offer to buy the company requests that the board do so. This is the issue the Delaware Supreme Court left open in the Household International decision. 
Grand Metropolitan v. Pillsbury [558 A. 2d 1049 (Del. Ch. 1988)]. In January 1986, Pillsbury's board of directors adopted a poison pill that distributed preferred stock purchase rights to all stockholders. In the event of a tender offer for the company's shares or in the event that a person or group acquired 20 percent of the shares, each right entitled its nontendering holder (or its holder owning less than 20 percent of the stock) to purchase $\$ 200$ worth of Pillsbury stock for $\$ 100$. In 1988, Grand Metropolitan commenced a tender offer for 100 percent of Pillsbury. The offer was contingent upon Pillsbury's redemption of the rights, which Pillsbury's board refused to do.

The Delaware Court of Chancery, applying the Delaware Supreme Court's test in Household International, found that Pillsbury's decision to keep its pill in place by not redeeming the rights was not a reasonable response in relationship to any threat posed, and the court ordered Pillsbury's board to redeem the rights. The court distinguished the tender offer of Grand Metropolitan from coercive tender offers, pointing to the fair price offered for the Pillsbury shares and noting that the only threat that could be posed by Grand Metropolitan's all-cash/all-shares offer was that of inadequate value. The court found this latter threat to be minimal; indeed, the court relied on evidence that Pillsbury's share price would be substantially adversely affected should Pillsbury's board fail to redeem the rights.

The Delaware Supreme Court, in its recent decision in Paramount Communications v. Time [1990 LEXIS 50, Fed. Sec. L. Rep. (CCH) p94,938 (Del. Sup. Ct. February 26, 1990, as revised March 9, 1990)], has challenged the Pillsbury court's assumption that a hostile tender offer poses only two types of threats to a target company, that of unequal treatment of shareholders and that of unequal value received in an all-cash/all-shares tender offer. The court in Paramount, writing of defensive tactics generally, opined that a tender offer can pose threats that the Pillsbury court did not recognize. The Delaware Supreme Court has thus left open for further review the issues decided by the Pillsbury ruling.

City Capital Associates v. Interco [551 A. 2d 787 (Del. Ch. March 2, 1989)]. The same court that later decided Pillsbury also ordered redemption of the flip-in share purchase rights issued as part of Interco's attempt to defend against a takeover bid by City Capital. The Delaware court found that City Capital's all-cash tender offer for all outstanding shares of Interco was noncoercive and that the only valid role for a shareholder rights plan in such circumstances was to give the target board time to consider its alternatives. 
Because the Interco board had ample time to consider its alternatives on behalf of Interco's shareholders, the board's decision not to redeem its share purchase rights could only be justified if the City Capital offer was so inadequate as to threaten the interests of Interco shareholders. The court found that City Capital's offer did not represent such a threat and ordered Interco's board to redeem the rights.

TW Services, Inc. v. SWT Acquisition Corp. [Fed. Sec. L. Rep. (CCH) 094,334 at 92,173 (Del. Ch. March 2, 1989)]. SWT announced a tender offer for TW Services in 1988, conditional on the redemption of rights issued as part of TW Services' poison pill and conditional on merger negotiations between the two companies. TW Services refused to redeem its rights on the grounds that the offer was not in the best interests of the company in the long term. Because redemption of the rights would represent a significant deviation from the target's long-term corporate plan, the court upheld the board's refusal to redeem the rights under the traditional Business Judgment Rule. The board's response to SWT's tender offer, like a response to an invitation to negotiate a merger, was within the discretion of 'TW Services' board. The court distinguished this case from those in which a target's board has already indicated its decision to maximize shareholder value in the short term.

Amanda Acquisition Corp. v. Universal Foods Corp. [708 Fed. Supp. 984 (E.D. Wis. 1989), affirmed on other grounds 877 F. 2d 496 (7th Cir. 1989)]. The district court, applying Delaware law, found that a target's board need not redeem flip-in rights in response to a coercive all-cash/all-shares tender offer. Universal's plan contained both flip-in and flip-over provisions. The flip-in provision was to be triggered by the acquisition of 20 percent of the company's shares and would entitle holders of the flip-in rights to purchase Universal shares at a 50 percent discount. The court found that Universal's flip-in provision, should Amanda acquire 75 percent of Universal, would result in a $\$ 115$ million drop in Amanda's equity stake (Universal, p. 1007). The court nevertheless found that the tender offer represented a significant threat to the corporation's various constituencies and that the board was therefore justified in its refusal to redeem the flip-in rights.

\section{Note Purchase Rights Plans (Back-End Plans)}

Note purchase rights plans, like share purchase rights plans, can provide an effective means for fending off unwanted suitors. In a notes purchase rights plan, the corporation issues rights to shareholders that, upon the occurrence 
of a triggering event, entitle holders to exchange shares of stock for a specified package of securities, including cash, stock, and debt. The triggering event is usually the acquisition of, or the announcement of a tender offer for, some percentage of the corporation's shares by any single entity. The package of securities may include conditions, such as financial ratio limitations, that restrict the ability of the potential acquirer to finance a takeover.

Revlon, Inc. v. MacAndrews \& Forbes Holdings, Inc. [506 A 2d 173 (Del. 1986) ]. In response to an impending hostile takeover bid from Pantry Pride, Revlon's board adopted a notes purchase rights plan in August 1985. Under the plan, each Revlon shareholder received a right entitling the holder to exchange one common share for a $\$ 65$ principal Revlon note at 12 percent interest with a one-year maturity. The right was to be triggered whenever anyone acquired 20 percent or more of Revlon's shares, unless the purchaser acquired 100 percent of Revlon's shares for at least $\$ 65$ a share. The rights would not be available to an acquirer, and Revlon's board could redeem the rights for 10 cents each (Revlon, p. 177).

In reviewing the rights plan and the various other issues relevant to the battle for Revlon, the Delaware Supreme Court observed that the plan was a reasonable response in relation to the threat posed by Pantry Pride's inadequate tender offer and that Revlon's board had acted in good faith and after reasonable investigation. The court also noted that the adoption of the rights plan was effective, leading in part to a rise in Pantry Pride's bids from $\$ 42$ a share to $\$ 58$ a share. In short, the court upheld the validity of the notes purchase rights plan. The case was decided against Revlon on other grounds, however.

Spinner Corp. v. Princeville Development Corp. [Fed. Sec. L. Rep. (CCH) P93,058 (D. Hawaii October 31, 1986)]. In 1986, Princeville adopted a back-end rights plan in response to a tender offer from Spinner. Under the plan, each shareholder received one right for each share owned. In addition to flip-in and flip-over provisions, each right entitled its holder to exchange each share of Princeville for a secured promissory note of "fair" amount if any person or group acquired more than 50 percent of Princeville's outstanding shares. The person or group acquiring 50 percent would not be entitled to this option. Once triggered, the rights could not be redeemed. The district court, distinguishing Colorado statutory law from the law of Delaware, ruled that Princeville's back-end plan discriminated between 50 percent nonapproved shareholders and others and held that the back-end plan was therefore invalid 
under a Colorado law forbidding issuance of different rights to shareholders of the same class.

Dynamics Corp. of America v. CTS Corp. [805 F. 2d 705 (7th Cir. 1986)]. In March 1986, CTS adopted a back-end plan in response to a lengthy and complex legal battle with Dynamics. Under the plan, each CTS shareholder would receive a right to exchange his shares for one-year notes with a principal amount of $\$ 50$ and bearing interest at 10 percent a year. The rights were to become exercisable and could trade separately if any person or group acquired beneficial ownership of 28 percent or more of CTS common stock. The acquirer would not be entitled to the exchange. Additionally, if an acquirer purchased 28 percent of CTS and simultaneously announced its intention to buy all remaining CTS shares for $\$ 50$ cash a share, the rights would not be exercisable until 120 days after the 28 percent purchase. If, within this time period, the acquirer completed the cash purchase of the remaining shares, then the rights were to be extinguished.

The plan was adopted by the CTS board, on the recommendation of a committee of outsider directors, after the courts had rejected a previous plan based on a flip-in provision. Dynamics challenged the back-end plan. The district court upheld CTS' use of the back-end plan under Delaware law, finding that the CTS board acted in good faith and upon a reasonable investigation and that the plan was a reasonable response to a perceived threat. This decision by a court that had previously expressed general disapproval of poison pills was a significant victory for poison pill advocates.

Buckhorn, Inc. v. Ropak Corporation [656 F. Supp. 209 (S.D. Ohio), affirmed by summary order 815 F. 2 d 76 (6th Cir. 1987)]. On November 24 , 1986, Ropak commenced an all-cash/all-shares tender offer for Buckhorn. In response, Buckhorn took several measures, including the adoption of a backend rights plan. The plan provided for an issue of 6 rights per share of Buckhorn common held and 10 rights per share of Buckhorn preferred held. Upon acquisition by anyone of more than 50 percent but less than 100 percent of Buckhorn, the rights entitled their holders to exchange their common and preferred shares for subordinated notes or for shares of new preferred, with a value fixed by the Buckhorn board. The rights would not be triggered if the acquirer paid at least $\$ 6$ per common share and $\$ 10$ per preferred share. The rights were to be redeemable at any time at a nominal price, if so voted by directors not elected by Ropak. 
Ropak challenged Buckhorn's poison pill in the District Court for the Southern District of Ohio. The district court, applying Delaware law, found that Buckhorn's board had reasonably perceived Ropak's tender offer as inadequate and a threat to the interest of shareholders on the back end of the offer. It also found that the board arrived at this perception in good faith following a reasonable investigation. The court found that Buckhorn's poison pill was a reasonable response to the threat perceived. The court also found, however, that Buckhorn's board had not adequately investigated the prices to be offered in the stock-for-notes or the stock-for-new-preferred exchange contemplated by the rights plan. Because Buckhorn's board had not provided proof of a reasonable basis for the pricing of the stock to be exchanged, the court rejected the pill.

\section{Value Assurance Plans}

The value assurance plan is a variation on the notes purchase rights plan. Under this type of defensive measure, stockholders are issued notes the value of which is contingent upon triggering events. The notes protect stockholders in the back end of a two-tiered tender offer by guaranteeing those stockholders a price that the target's board considers fair.

Mayflower Group, Inc. Mayflower Group designed a value assurance plan in response to a tender offer by Laidlaw Transportation. The plan entailed a dividend issue of contingent two-year notes, transferable at the time of issue. If a potential acquirer acquired 30 percent of Mayflower's common stock, then the principal amount of the notes would be fixed at a price reflecting the difference between what Mayflower's board thought to be a fair price per share of the company's common stock and the price paid by the acquirer for the shares acquired (using a weighted average of the prices paid in the 30 percent acquisition). The effect of this first provision would be to grant those shareholders who held onto their shares the benefit of the price received by those who sold their shares to the acquirer.

A second provision provided that if no acquisition occurred, the principal amount of the notes would be set at an amount reflecting the difference between the average Mayflower share price on the market and the price of a share in the Laidlaw tender offer, taking into account interest adjustments. The purpose of this second provision was to encourage stockholders not to tender their shares to Laidlaw but instead to await maturity of the two-year notes. 
Newmont Mining Corporation. In response to a partial tender offer by Ivanhoe Partners, Newmont Mining introduced a value assurance plan. Under the plan, holders of rights would be entitled, in the event of a business combination, to the difference between the highest price paid for Newmont shares in the acquisition period and the price paid to shareholders in the backend offer. The goal of this plan was to ensure that all target shareholders would receive the highest price received by any shareholder.

Firestone Tire \& Rubber Co. A variation on value assurance plans is that adopted by Firestone in February 1988. The plan called for the issue of "preferred stock value rights," which serve to guarantee that holders receive the benefits of any business combination. The rights are issued to current shareholders of the target and become exercisable at a minimal price of 1 cent per right if any entity acquires 20 percent of the target. Those holders who have exercised their rights are then entitled to share the proceeds of subsequent sales of significant assets or equity interests of the target. The proceeds of sales of assets or equity interests are kept in trust for three years, after which they are distributed to those who exercised the rights.

\section{Super Voting Rights/Preferred Stock Dividend Plans}

Like traditional preferred stock dividend plans, the super voting rights plans entail issuing new preferred stock to existing holders of common stock. What super voting rights plans have to offer in addition are increased voting rights awarded the holders of the newly issued preferred. The new preferred carries with it higher voting rights than the common stock and is convertible to common stock. These plans shift the voting power within the target corporation, and most courts have refused to uphold such plans on the grounds that they shift voting control away from certain shareholders without paying them a control premium.

Asarco, Inc. v. Court [611 F. Supp. 468 (D. N.J. 1985)]. Asarco announced a preferred stock dividend plan in response to an open market accumulation by a number of entities operating with Weeks Petroleum. According to the plan, holders of Asarco common were to be issued 1 share of preferred for every 10 shares of common stock held. The new shares, among other provisions, were entitled to 50 votes per share once a potential acquirer obtained 20 percent or more of Asarco stock. The potential acquirer would be entitled to no voting rights on the preferred shares. The effect of this plan, should an acquirer obtain 20 percent of Asarco common, would have been to 
reduce a 20 percent ownership interest to an 8.9 percent voting interest (Asarco, p. 471). A federal district court prevented the preferred issue. The court applied a New Jersey law against different voting rights among shares of the same class of stock and found that the extreme effect of the Asarco preferred plan violated this law.

City Federal Savings \& Loan Association v. Mann [C.A. No. 84-4010 (D. N.J. August 2,1985$)]$. Another type of voting rights plan was adopted by City Federal. The plan entailed an issue of new preferred to all holders of City Federal common stock. The preferred carried with it one vote, unless the preferred holder had acquired 5 percent of City Federal preferred or 15 percent of all City Federal voting stock. In this latter case, a holder of the preferred would be entitled to $1 / 100$ of a vote. The federal district court, applying Delaware law, let the City Federal plan stand.

UnileverAcquisition Corp. v. Richardson-Vicks, Inc. [618 F. Supp. 407 (S.D. N.Y. 1985)]. In response to Unilever's bid for control of Richardson-Vicks, the latter adopted a super voting rights plan. Holders of the new RichardsonVicks preferred were entitled to super voting rights only if they had acquired it on initial issue or if they had held the stock for more than three years. The plan would have effectively reduced the voting power of any potential shortterm acquirer. The federal district court held that the Richardson-Vicks plan violated Delaware law and the corporation's charter by restricting alienability (transferability) of the stock and by restricting the voting power of holders of Richardson-Vicks common stock.

Minstar Acquiring Corp. v. AMF, Inc. [621 F. Supp. 1252 (S.D. N.Y. 1985)]. AMF in 1985 adopted a poison pill providing for an issue of nontransferable rights to purchase both debentures and shares. The rights were to be triggered by the acquisition of 30 percent or more of the company in the absence of a plan approved by AMF's board to acquire 100 percent of the company (Minstar, p. 1256). The preferred also carried with it a class vote on mergers. A federal district court found that the plan was invalid under New Jersey law because it restricted the offering of rights to shareholders on a given date, thus leaving out shareholders who had received their shares after that date. This effectively created two classes of shareholders out of one class, contrary to New Jersey law. 


\section{Appendix 2.}

\section{The Williams Act of 1968 (Amendments to the Securities Exchange Act of 1934)}

A complete understanding of the poison pill is not possible without reference to the rules regulating tender offers and to the coercive behavior those rules may elicit. Relatively few rules pertain to hostile takeovers, and most of the existing ones are procedural. By 1966, 107 cash tender offers had been made for exchange-traded companies; the technique was increasingly being used to displace intransigent target management. Tender offers in which the offerer's securities were used as consideration were subject to the disclosure and antifraud rules of the Securities Act of 1933, but these rules did not apply to cash tender offers. Thus, before 1968, cash tender offers were essentially unregulated. Congress addressed this void with the Williams Act (Gilson 1986, pp. 934-35).

The Williams Act, enacted in 1968, constrained the conduct of unsolicited acquisitions in the 1970s and 1980s by requiring timely and full disclosure of a raider's equity interest, intentions, and offers to buy. The Williams Act added subsections (d) and (e) to Section 13 and subsections (d), (e), and (f) to Section 14 of the Securities Exchange Act of 1934. These provisions regulate tender offers, open market purchases, and repurchases by the issuing organization of securities that are either listed on a national securities exchange or registered under Section 12 (g) of the Securities Exchange Act.

\section{Terms of the Act}

The phrase "tender offer" is not defined in the Williams Act, but it is commonly understood to mean a public offer to purchase securities made otherwise than in an organized securities market by communication of the offer directly to all of the existing holders of the securities that are desired to be purchased (Jennings and March 1982, p. 690).

Section 13(d) states that, in general, a person who acquires 5 percent of a class of equity securities must file a Schedule 13D with the Securities and Exchange Commission (SEC) within 10 days after reaching this threshold. An unlimited amount of shares may be purchased before the filing, but there is a 10-day moratorium on purchasing additional shares after the Schedule 13D filing. Disclosures required on Schedule 13D include: 
- Securities purchased and the issuer;

- Name and background of filer;

- Amount and source of consideration;

- Purpose of transaction (this is the subject of most litigation);

- Interest in target company's securities; and

- Relationship between filer and company.

Section 14(d) requires a filing with the SEC and transmittal to the target of information regarding the maker of a tender offer and the maker's intentions concerning the target corporation. All bidders, defined as those making a tender offer or on whose behalf a tender offer is made, and persons acting as in a partnership or other group for purposes of buying the target, must file Schedule 14D-1. Disclosures required on Schedule 14D-1 include:

- Names of the bidder and the target company;

- Title of class of securities being purchased;

- Names and addresses of all persons reporting under the schedule and disclosure of whether they belong to a "group";

- Source of funds used in the tender offer;

- Disclosure of any criminal convictions within the past five years of the person who presents the tender offer;

- All past contracts or negotiations between the tender offeror and the target company; and

- All persons compensated in connection with the tender offer and disclosure discussions.

Section $14(e)$ is the antifraud provision, which prohibits material misstatements, omissions, and fraudulent practices concerning tender offers. The tender offeror must hold open his offer for at least 20 business days from the date of the first publication of the offer. Terms of the offer may not be increased for at least 10 business days after publication of the notice of increase. The length of the tender offer may not be extended unless a notice of the extension is published. Within 10 days of the tender offer, the target company must recommend acceptance or rejection of the tender offer, express no opinion with a decision to remain neutral, or state that it is not able to take a position.

Rule 14e-3 prohibits insider trading during a tender offer, and Section 14(f) defines disclosure requirements concerning directors. 


\section{Coercive Elements of the Williams Act}

The poison pill preferred stock was originally invented to counter certain coercive behavior by raiders not proscribed by--and possibly induced by-the Williams Act. Senator Williams noted that the Act was designed solely to require full and fair disclosure for the benefit of investors (Harvard University Law School 1984, p. 1981). The intent of the bill may have been to level the playing field between bidders and management, but the resulting structure is perceived by many to invite and stimulate two-tiered cash tender offers and partial tender offers. These tactics are designed to minimize the gains of the "free-riding" shareholder who would otherwise profit from the bidding action without doing anything to create those profits. Through its full disclosure requirements, the Williams Act may assist free riders.

In a two-tiered tender offer, a bidder offers a higher price for the controlling share of the business than for the remainder of the shares, and shareholders have a powerful incentive to tender their stock immediately to avoid being forced to receive a lower price later or to assume a minority position under new management. In a partial tender offer, the bidder tenders for some, not all, of a firm's stock (for example, 51 percent). Those target shareholders who do not tender risk later abuse by the raider through a minority freeze-out; a low-price, clean-up tender offer; or subtle forms of self-dealing.

Under the Williams Act, the only protection against two-tiered tender offers left to dissenting shareholders in the absence of fraudulent or unlawful corporate acts is appraisal under state law, which is limited to a cash payment equal to the court's valuation of fair market value. Class-action relief is not available in appraisal hearings, and thus their usefulness is restricted to persons with enormous individual losses. As a consequence, state appraisal laws allow a wide divergence between the first- and second-tier prices, leaving untouched the most coercive elements of the two-tiered offer. 


\section{Appendix 3.}

\section{Technical Supplement to the Simulation Analysis}

The value effect of the poison pill was defined in Chapter 4 to be equal to the difference between the expected present value of cash flows to shareholders under management's strategy (as protected by the pill) and the raider's strategy (as implemented in the absence of the pill). The simulation model estimates these differences over many repeated trials.

In each trial, "cash flow" to shareholders was simply the proceeds of selling a share of stock at the earlier of a raider's bid or the terminus of the investment 10 years hence. At first glance, the treatment of cash flows seems assymetric. Under the pill, investors are assumed to buy and hold for the long term, whereas if raiding is permitted, investors can cash out early. The reason for this is to capture the possible future benefits from letting the incumbents pursue their strategy. It was assumed that no dividends were paid and no shares purchased or otherwise issued. Also, for simplicity, it was assumed that the target firm had no debt and that therefore the value of equity and the value of the firm are synonymous.

The stock price was initially set at $\$ 25.00$ and thereafter followed a random walk each month for 10 years (120 months), the term of a typical poison pill. The restructuring value was initially seeded at $\$ 25.00, \$ 16.66$, or $\$ 33.33$ (that is, $+/-33$ percent) and thereafter allowed to follow a random walk each month for 10 years. Stock price and restructuring value were constrained to a minimum of $\$ 1.00$ but otherwise were assumed to vary according to a normal distribution each month with a mean of zero and a standard deviation set at $4.33,9.24$, or 18.76 percent. These monthly deviations annualize to 15,32 , and 65 percent, respectively. (Assuming the monthly deviations are not autocorrelated, a monthly deviation is annualized by multiplying it by the square root of 12.)

The assumptions underlying the stock price forecast are perhaps the most significant in the simulation. The simulations reported here assume a random walk with zero growth trend. Assuming a random walk is reasonably consistent with the results of academic research on the time path of stock prices. Rates of inflation or real growth could add a trend to the progression, although this matters only if the growth rates associated with the incumbent's and raider's strategies are different. If the raider's growth trend exceeds the 
incumbent's, the negative effect of the pill reported here is underestimated; if the converse is true, the effect is overestimated. The assumption of no difference is neutral.

At each month, the raider was assumed to decide whether to attack and to attack only if the prospective return on investment (ROI) met or exceeded his target (arbitrarily set at 30 percent). Whether the ROI target was met was determined by the restructured value of the firm relative to its current trading value (that month). Therefore, the raider's attack rule was:

$$
\text { Attack if : } \frac{\text { (Restructured value - value paid) }}{\text { value paid }}>30 \% \text {. }
$$

If the raider attacked, the raider was always assumed to win.

Each simulation was conducted with 100 trials (selected simulations were conducted with 1,000 trials, but doing so produced no material difference in results), using “@Risk," add-on software to Lotus 1-2-3. The specific sampling procedure was Latin Hypercube, which forces the samples drawn to correspond with the input distribution and converges faster than Monte Carlo simulation on the true statistics of the input distributions. 


\section{GLOSSARY OF TERMS}

Agency theory: An economic theory about relations between agents and principals, based on an analysis of incentives, payoffs, information, and risk unique to each party.

Authorization to issue preferred stock: A provision that permits a board of directors to issue preferred stock in defense against a hostile tender offer. The provision also may specify special voting rights for this issue and/or poison pill provisions. The preferred stock so issued deters raiders through the voting or economic dilution imposed on them.

Back-end plan: A form of poison pill that gives common shareholders the right to exchange their shares for a specified amount of cash, stock, and/or notes. The rights are exercisable when an entity has acquired a specified percentage of the company, but the large blockholder is excluded from the exchange plan. Because the value of the exchange is set above the market value of the company's stock, the effect of the plan is to increase the cost of acquiring the company.

Blank check: Previously authorized issuance of a large block of preferred stock with no attached provisions. Such preauthorization enables a firm to institute a poison pill defense quickly.

Business Judgment Rule: (Delaware.) Directors of corporations discharge their fiduciary duties when in good faith they exercise business judgment in making decisions regarding their corporations. When they act in good faith, they enjoy a presumption of sound business judgment, reposed in them as directors, which courts will not disturb if a rational business purpose can be attributed to their decisions. In the absence of fraud, bad faith, gross overreaching, or abuse of discretion, courts will not interfere with the exercise of business judgment by corporate directors.

Classified board of directors: A board to which directors are elected in classes or fractions, typically one-third in any given year. Thus, the composition of the board cannot change radically or quickly. The defense is usually accompanied by a supermajority provision. See also Staggered board. 
Coercive tactics: See Street sweep, Two-tiered tender offer, and Market accumulation program.

Control coalition benefits: Advantage of controlling shareholders by which they may appropriate for themselves excess compensation for managerial positions, use the firm's resources, and adjust the payment of dividends to meet their cash flow needs. Quasi-financial benefits include expense accounts, plush offices, and automobiles. Controlling shareholders are better informed than minority shareholders, their investment uncertainty is reduced, and they have access to information from and about customers.

Control premium: Proportion of share value based on control status. On a per-share basis, investment in controlling shares is more valuable than that in minority shares because the investor is able to implement what he believes to be the best policies in the management of his investment. The control premium tends to be larger as the control group gets smaller. It tends to be larger in small, closely held companies than in large, publicly held companies. Control premiums tend to be low when ownership of voting control is concentrated in the hands of principal officers and directors. In this case, the observed market value represents the marginal value of noncontrolling shares, because no transfer of control is likely to occur.

Control share acquisition feature: A provision under which a shareholder purchasing more than a 20 percent interest in a company loses voting rights on the shares he owns. The stockholder can regain voting rights only if the rights are granted by a vote of a majority of "disinterested" shareholders, defined as those shareholders who are affiliated neither with company management nor with the large stockholder.

Creeping acquisition: Occurs when a raider quietly accumulates up to 5 percent of a company and continues to buy stock for the 10 days before any disclosure is required. Purchases are typically made through obscure corporations and partnerships to conceal the identity of the acquirers. Before crossing the 5 percent threshold, the bidder typically firms up its buying group and obtains the financing required for its planned stock purchases. The raider then crosses the 5 percent threshold and commences a vigorous open market purchase program. Usually an acquirer will be able to accumulate up to 10 
percent of the target's shares in the 10-day period before disclosing such purchases or any aspect of its plan.

Dual-class common stock: A scheme of classifying equity claims on a firm, typically on the basis of different voting rights. A number of corporations have sought to protect themselves against takeovers by creating a class of common stock with superior voting power and concentrating ownership of that class of stock in the hands of corporate management, employees, or "friendly" outside investors.

\section{Exclusionary tender offer: See Greenmail.}

Fair price provisions: Corporate charter or bylaw provisions requiring a bidder to pay the same price for all shares purchased. The intention is to prevent two-tiered takeover bids, in which one price is offered for a controlling interest of the target's stock and a lower price is offered for the remainder.

Fiduciary. A person who stands in a special relation of trust, confidence, or responsibility in his obligations to others, as a company director or an agent of a principal.

Flip-in provision: A provision by which a target company grants its shareholders rights to purchase additional common or preferred shares of the target at a deep discount if a large block of stock of the target is purchased in a transaction that is not approved by the board of directors. The provision is triggered automatically by an acquirer crossing a specified ownership threshold, and it operates by the issuance of substantial amounts of new target common stock at a deeply discounted price to all target shareholders but the acquirer. The acquirer's holdings suffer a substantial dilution in value.

Flip-over provision: A provision by which a target company grants its shareholders rights to purchase common or preferred shares of the acquiring company at a deep discount if a large block of stock of the target is purchased in a transaction that is not approved by the board of directors. The provision is intended to discourage two-tiered tender offers by causing the merger of the firm to be prohibitively expensive. 
Forced equity provision: A provision enabling the target's preferred shareholders to convert their stock directly into common stock of the acquirer.

Freeze-out: A type of merger in which a group or company that has obtained a controlling interest in another company forces the remaining shareholders to give up their interest in that company, often at unfavorable terms.

Front-end-loaded tender offer: See Two-tiered tender offer.

Golden parachutes: Employment contract provisions that guarantee very substantial severance payments to top management if they lose their jobs as the result of a takeover.

Greenmail: A payment made in connection with, or in a transaction related to, the acquisition of target company shares by a bidder, when the following conditions are met (to satisfy the requirements for the 50 percent excise tax on gains attributed to greenmail):

1. The bidder has held the stock for less than two years;

2. At any time during the two-year period prior to the purchase, the bidder, or other persons acting in concert with the bidder, made or threatened to make a public tender offer for the target's shares; and

3. The acquisition is pursuant to an offer that was not made to all target shareholders.

Market accumulation program: Maneuver used by hostile bidders to avoid a tender offer. Normally, a third party accumulates a large block of stock and negotiates its purchase with an acquirer. The third party acts as an agent and does not actually own the stock. See also Street sweep.

Partial tender offer: An offer to buy at least a controlling interest in a corporation but less than all its shares.

Poison pill: Preferred stock dividend or share purchase right issued to the target's shareholders that has special features enabling its conversion to shares of the acquirer. In a broader context, the term poison pill refers to the defensive issuance of any securities that can be converted to cash, notes, or stock of the acquirer. Dilution of the bidder serves to deter acquisition. 
Proxy battle: Struggle between a company and dissident shareholders. The battle is precipitated by the solicitation of proxies by dissident shareholders to obtain approval of a shareholder resolution or to change the composition of the board of directors.

Redemption: Repayment of a debt security or preferred stock issue, at or before maturity, at par or at a premium price. The repurchase of shareholder stock purchase rights.

Shareholder consent solicitation: A special proxy solicitation. Although proxies must be submitted at a shareholder meeting, consents can be solicited without having to wait for a meeting.

Shark repellent: Provisions in a corporate charter and bylaws designed to discourage unwanted takeovers. Shark repellents generally impede, rather than prevent, rapid assumption of control.

Staggered board: Arrangement of a board of directors whereby members are elected at staggered intervals. As a result, a hostile aggressor cannot gain control of a company immediately but must wait until the directors' terms of office expire. See also Classified board of directors.

Street sweep: The purchase of large blocks of stock from arbitrageurs following the cancellation of a tender offer. Using this method, bidders can gain control of a large percentage of a company's stock quickly, without using the tender process.

Supermajority provision: Requirement of a corporation's bylaws related to certain decisions such as mergers and director selection. These provisions require a substantially higher proportion of votes than the state law mandates.

Tender offer: Public offer to buy some or all of the shares of a public company that is or would be required to be registered with any federal or state agency regulating securities. Notice of the offer must be filed with the SEC on Schedule 14D-1, disclosing, among other things, certain financial information about the bidder. Because the offer is made directly to the target's shareholders, this type of takeover approach enables a bidder to acquire control of 
the target without the approval of the target's board of directors and without a shareholder vote.

Two-tiered tender offer: A partial tender offer, usually paid in cash, for a controlling interest in a corporation's stock, followed by a second-step merger. The second step is accomplished at a lower price, usually by means of an exchange of stock or a combination of cash and stock, which reduces the bidder's cash cost. Bidders using this technique hope that shareholders will "stampede" to tender their shares for the higher price offered on the front end of the deal, regardless of the wishes of the target company's management. This type of offer is also known as a front-end-loaded tender offer. This tactic is criticized as being coercive to shareholders. 


\section{REFERENCES}

Analysis Group, Inc. 1988. "The Effects of Poison Pills on Shareholders: A ReAnalysis of Georgeson's Sample." Belmont, Mass. (December).

Augliera, A. 1989. "Shareholder Rights Plans: Saying No to Inadequate Tender Offers." Fordham Law Review 57: 803-33.

Austen-Smith, D. and P. C. O'Brien. 1986. "Takeover Defenses and Shareholder Voting." Cambridge, Mass.: Massachusetts Institute of Technology (September). Manuscript.

Bergin, P. R. 1988. Voting by Institutional Investors on Corporate Governance Issues in the 1988 Proxy Season. Washington, D.C.: Corporate Governance Service, Investor Responsibility Research Center (November).

Berkovitch, E. and N. Khanna. 1990. "How Target Shareholders Benefit from ValueReducing Defensive Strategies in Takeovers." Journal of Finance 45 (March): 137-56.

Block, D. J. and H. L. Pitt. 1990. Hostile Battles for Corporate Control, Vol. 1. New York: Practising Law Institute.

Brickley, J.A, R.C. Lease, and C.W. Smith, Jr. 1988. “Ownership Structure and Voting on Antitakeover Amendments." Journal of Financial Economics 20 (January/March): 267-91.

Burrough, B. and L. P. Cohen. 1987. "Poison Pill' Inventor, Conceding Snags in Defense Plan, Prescribes New Remedy." Wall Street Journal (May 20).

Coates, J. C., IV. 1989. "State Takeover Statutes and Corporate Theory: The Revival of an Old Debate." New York University Law Review 64 (October): 806-76.

Coleman, G. 1989. “Canadian Poison Pills: Are They Effective?" International Financial Law Review 8 (June): 12-14.

Cox, J.C. and M. Rubinstein. 1985. Options Markets. Englewood Cliffs, N.J.: Prentice-Hall.

Cranford, J. R. 1988. “Anti-takeover Bill Pulled from Senate Floor.” Congressional 
Quarterly (June 25): 1717-18.

DeAngelo, H. and E. M. Rice. 1983. "Antitakeover Charter Amendments and Stockholder Wealth." Journal of Financial Economics 11: 329-59.

Easterbrook, F. and L. Fischel. 1981. "The Proper Role of a Target's Management in Responding to a Tender Offer." Harvard Law Review 94: 1145.

Georgeson \& Company, Inc. 1988a. "Poison Pill Impact Study." New York.

_ 1988b. "Poison Pill Impact Study II." New York.

Gibbens, R. 1989. "Canada Wises up to the Poison Pill." Financial Times (December 27).

Gilson, R. J. 1986. The Law and Finance of Corporate Acquisitions. Mineola, New York: The Foundation Press.

Gilson, R. J. and R. Kraakman. 1990. "Reinventing the Outside Director: An Agenda for Institutional Investors." Working Paper 66. Stanford, Cal.: Stanford Law School (August).

Harvard University Law School. 1984. "Protecting Shareholders against Partial and Two-Tiered Tender Offers: The Poison Pill Preferred." Harvard Law Review 77: 1964-83.

Heard, J. E. 1988. "Poison Pill Study Lambasted." Pensions and Investment Age 16 (April 18): 34.

Hilder, D. B. 1989. “TW Services' Poison Pill Ploy Upheld in Court." Wall Street Journal (March 3): A4.

Investor Responsibility Research Center. Annual, 1985-89. "Voting by Institutional Investors on Corporate Governance Issues." Washington, D.C.: Corporate Governance Service.

Jarrell, G. A. and A. B. Poulsen. 1986. "Shark Repellents and Poison Pills: Stockholder Protection-From the Good Guys or the Bad Guys?" Midland Corporate Finance Journal 4 (Summer): 39-47. 
- 1987. "Shark Repellents and Stock Prices: The Effects of Antitakeover Amendments Since 1980." Journal of Financial Economics 19: 127-68.

Jarrell, G. A., J. A. Brickley, and J. M. Netter. 1988. "The Market for Corporate Control: The Empirical Evidence Since 1980." Journal of Economic Perspectives 2 (Winter): 49-68.

Jennings, R. W. and H. March, Jr. 1982. Securities Regulations. Mineola, New York: The Foundation Press.

Jensen, M. C. 1987. "The Takeover Controversy: Analysis and Evidence." Midland Corporate Finance Journal 4: 6-32.

- 1988. "Takeovers: Their Causes and Consequences." Journal of Economic Perspectives 2 (Winter): 21-48.

Johnson, L. and D. Millon. 1989. “Misreading the Williams Act." Michigan Law Review 87: 1862-1923.

Karpoff, J. M. and P. H. Malatesta. 1990. "PA Law: State Antitakeover Laws and Stock Prices." Financial Analysts Journal (July/August): 8-10.

Kelly, E. J. 1987. "The Origin and Development of the Fair Price Clause." Securities Regulation Law Journal 15 (Fall): 267-95.

Kidder Peabody \& Co., Inc. 1986. Impact of Adoption of Stockholder Rights Plans on Stock Prices. New York.

Knoeber, C. R. 1986. "Golden Parachutes, Shark Repellents, and Hostile Tender Offers." American Economic Review (March): 155-67.

Lee, E. D. 1988. "Heard on the Street: 'Poison Pills' Benefit Shareholders by Forcing Raiders to Pay More for Targets, Study Says.” Wall Street Journal (March 31): C55.

Lewis, S. D. 1990. "Why States Are Stepping Up Attacks on Large Mergers.” Mergers and Acquisitions (July/August): 35-40.

Lewkow, V. I. and W. A. Groll. 1990. "Poison Pills and Other Structural Defenses: Uses and Abuses in the Age of Saying 'No'." Hostile Battles for Corporate Control- 
1990, Vol. 2. New York: Practising Law Institute.

Linn, S. C. and J. J. McConnell. 1983. "An Empirical Investigation of the Impact of 'Antitakeover' Amendments on Common Stock Prices." Journal of Financial Economics 11: 36-99.

Lipton, M. 1987. "Corporate Governance in the Age of Finance Corporatism." University of Pennsylvania Law Review 136 (November): 1-72.

— 1990. "Hostile Bank Acquisitions." New York: Wachtel, Lipton, Rosen \& Katz (April 27).

Lipton, M. and S. A. Rosenblum. 1990. "A Proposal for a New System of Corporate Governance: The Quinquennial Election of Directors." New York: Wachtel, Lipton, Rosen \& Katz (October 22).

Lipton, M. and E. Steinberger. 1989. Takeovers \& Freezeouts, Release 9. New York: Law Journal Seminars-Press.

Lowenstein, A 1988. What's Wrong with Wall Street. Englewood Cliffs, N.J.: Prentice-Hall.

MacIntosh, J. G. 1989. "The Poison Pill: A Noxious Nostrum for Canadian Shareholders." Canadian Business Law Journal 15 (July): 276-334.

Malatesta, P. H. and R. A. Walkling. 1988. "Poison Pill Securities: Stockholder Wealth, Profitability, and Ownership Structure." Journal of Financial Economics 20: $347-76$.

Margotta, D. G. 1988. "Takeover Premiums: With and without Shareholder Rights Plans." Georgeson Report 353 (fourth quarter).

Matthewson, W. 1988a. "Shop Talk." Wall Street Journal (April 21): 33.

. 1988b. "Shop Talk." Wall Street Journal (November 21): B1.

McWilliams, V. B, 1990. "Managerial Share Ownership and the Stock Price Effects of Antitakeover Amendment Proposals." Journal of Finance 45 (December): 1627-40. 
Mergers \& Acquisitions. 1987a. "The Debt Repellent." (July/August): 21

. 1987b. "The Instant Recap Pill." (September/October): 22.

. 1988a. "New Looks for Old Pills." (March/April): 21.

. 1988b. "The Break-up Counterattack." (September/October): 22.

1990. "Compounding the Headache." (January/February): 20.

Metz, T. 1988. "Promoter of the Poison Pill Prescribes Stronger Remedy." Wall Street Journal (December 1).

Michel, A. and I. Shaked. 1986. Takeover Madness: Corporate America Fights Back. New York: John Wiley \& Sons.

Moore, S. M. and E. G. Schuck, Jr. 1988. "Tax Aspects of Defensive Strategies to Corporate Takeovers." Journal of Taxation (October): 212-13.

Neto, E. S. 1990. "Brazilian Poison Pills: Rare but Legitimate." International Financial Law Review 9 (February): 36-38.

Parker, M. 1988. "The Thrill of Victory." Pensions \& Investment Age 16 (June 13): 1.

Pitt, H. L., et al. 1990. "Tender Offers: Offensive and Defensive Tactics and the Business Judgment Rule," 679 Corporate Law and Practice Course Handbook Series. New York: Practising Law Institute.

Pound, J. 1987. "The Effects of Antitakeover Amendments on Takeover Activity: Some Direct Evidence." Journal of Law \& Economics, 30 (October): 353-67.

Pozen, R. C. 1989. "A Prescription: Give Poison Pills Expiration Dates." Wall Street Journal (Nov. 1): 14.

Pugh, W. N. and J. S. Jahera, Jr. 1990. "State Antitakeover Legislation and Shareholder Wealth." Journal of Financial Research 13 (Fall): 221-31.

Ribstein, L. E. 1989. "Takeover Defenses and the Corporate Contract." The Georgetown Law Journal 78: 71-151. 
Ruback, R. S. 1988. "An Overview of Takeover Defenses," in Alan Auerbach, ed., Mergers and Acquisitions, National Bureau of Economic Research. Chicago: University of Chicago Press.

Ryngaert, M. D. 1988. "The Effect of Poison Pill Securities on Shareholder Wealth." Journal of Financial Economics 20: 377-417.

. 1989. "Firm Valuation, Takeover Defenses, and the Delaware Supreme Court.” Financial Management (Autumn): 20-28.

Ryngaert, M. and J. Netter. 1987. "Shareholder Wealth Effects of the Ohio Antitakeover Law." Journal of Law, Economics and Organizations 4: 373-83.

Schumann, L. 1987. "State Regulations of Takeovers and Shareholder Wealth: The Effects of New York's 1985 Takeover Statutes." Washington, D.C.: Bureau of Economics Staff Report to the Federal Trade Commission.

Selby, B. 1989. “Borden's People Pill.” Institutional Investor (February): 27-28.

Strong, J. S. and J. R. Meyer. 1990. “An Analysis of Shareholder Rights Plans.” Managerial and Decision Economics 11 (May): 73-86.

Thompson, P. J. 1989. “Shareholder Rights Plans: Shields or Gavels?” Vanderbilt Law Review 42: 173-208.

Valente, J. 1988a. "Santa Fe Southern Holders Vote to Kill Poison Pill, Against Management Wishes." Wall Street Joumal (May 25): 3.

- 1988b. "Santa Fe Southern Faces Thorny Issue of Whether to Accept Vote on Poison Pill." Wall Street Joumal (May 26): 14.

Wall Street Journal. 1988. "Tax Report." (October 26).

Yablon, C. M. 1989. "Poison Pills and Litigation Uncertainty." Duke Law Joumal 1989: 54-91. 